\title{
Dilde Mekânı (Yeniden) Kurgulamak: Yer İsimleri, Kolektif Bellek ve İdeoloji
}

\author{
Seda Arslan ${ }^{1}$ \\ ORCID: 0000-0003-0973-8071
}

\author{
Zeynep Uludağ ${ }^{2}$ \\ ORCID: 0000-0001-9242-7957
}

\section{Öz}

Mekânın iletişimsel dili kentin anlatısını oluşturan işaret ve sembollerle doludur. Arkasında pek çok anlamı barındıran ve bize mesajlar ileten bu mekânsal çevre bizim deneyimlerimiz, davranışlarımız, bilişsel algımız ve hafizamızla birlikte sosyal ve kültürel bir anlatıya dönüşür. Kentin anlatısı, mimari mekânın yalnızca işlevsel, sosyal ve kültürel ilişkileri ile değil aynı zamanda ideolojik mesajlarla şekillenir. İktidar; mimarlık ve kenti ideolojileri doğrultusunda kullanırken biçim, malzeme, konum, mekânsal hiyerarşi, antssallık gibi somut tasarım araçlarına müdahale etmektedir. Ancak buna ek olarak siyasi otorite, mekânın tanımlanmasi ve adlandırılmasında kullandığg terminoloji ile (bazen fiziksel müdahaleye bile gerek kalmadan) mekân ve mekânsal pratikleri "dilde" dolayısıyla bellekte yeniden biçimlendirmektedir. Bu çalışma kentin anlatısının mekânsal imgelemlerle (yeniden) anlamlandırılması üstüne deneysel bir araştırmadır. Bu kapsamda; yer isimlendirme örnekleri anma/hatırlatma nitelikli kullanılan ön isimlerin (belirten) çağrışımları ve mekân türünü/tipolojisini tanımlayan terimlerin anlam yükleri üzerinden iki durum ile ele alınmış ve Türkiye'de siyasi bir pratik olarak yer isimlendirmelerinin güncel örnekleri incelenmiştir.

Anahtar Kelimeler: kentin anlatısı, mekânsal imgelem, kentsel yer isimleri, kolektif bellek, temsil mekânları

\footnotetext{
${ }^{1}$ Mimar/ Doktora Adayı, Gazi Üniversitesi, E-mail: seda.arslan@gazi.edu.tr

2 Prof. Dr. Mimar, Gazi Üniversitesi, E-mail: uzeynep@gazi.edu.tr
}

idealkent (c) Kent Araştırmaları Dergisi (Journal of Urban Studies) 


\title{
(Re)Structuring the Space in Language: Place Names, Collective Memory and Ideology
}

\author{
Seda Arslan ${ }^{3}$ \\ ORCID: 0000-0003-0973-8071
}

\author{
Zeynep Uludağ ${ }^{4}$ \\ ORCID: 0000-0001-9242-7957
}

\begin{abstract}
The communicative language of the space is full of signs and symbols that construct the narrative of the city. This spatial environment, which has many meanings behind it and conveys messages to us, turns into a social and cultural narrative with our experiences, spatial behavior, cognitive perception and memory. The narrative of the city takes shape not only through functional, social and cultural relations of the architectural space but also by ideological messages. Power interferes with concrete design tools such as form, material, location, spatial hierarchy and monumentality while using architecture and the city as a tool of building ideologies. However, in addition to this, the political authority restructures the space and spatial practices "in language", thus in memory, with the terminology it uses in the definition and place naming (sometimes without even physical intervention). This study is an experimental research on the (re)meaning of the narrative of the city with spatial imaginations. Within the scope of this work; place naming examples are explored under two cases; connotations of commemorative initial names (indicatives) and the semantic of term names that describe type of space / typology; also contemporary examples of place naming in Turkey are examined as a political practice.
\end{abstract}

Keywords: urban narrative, spatial imagination, urban place names, collective memory, representational space

\footnotetext{
${ }^{3}$ Architect / PhD Candidate, Gazi University, E-mail: seda.arslan@gazi.edu.tr

${ }^{4}$ Prof. Dr. Architect, Gazi University, E-mail: uzeynep@gazi.edu.tr
}

idealkent (c) Kent Araştırmaları Dergisi (Journal of Urban Studies) 


\section{Giriş}

Kenti, kültür gibi işaretler ve semboller sistemi olarak düşünebiliriz. Bu durumda insanların ona verdiği anlamların ve kentten aldıkları mesajların anlaşılması bir okuma alıştırmasına dönüşecektir. Ancak bu okumanın doğru ve genel yönteminin bulunması gerekir. Kentin anlatısı aynı dil gibi "düşünceyi tamamlayan", düşünceyi yaratan bir olgudur (Akarsu, 1984, s. 43). Bu olgu her türlü entelektüel etkinliğin de temelinde yatar. Bu bağlamda hem bireyin hem de ulusun dünya görüşünü temsil eder.

Kent sosyolojisindeki kuramsal çalışmalar kentin ya da başka bir olgunun analizi için uygun olan kentsel okumanın yöntemleri üzerinde yoğunlaşır. Farklı terimlerle olsa da pek çok kuramcı (Giddens, 1995; Harvey, 1975; Lefebvre, 1993; Sayer, 1991 gibi) doğru bir kentsel okumanın ancak mekân ve sosyal süreçler arasındaki ilişkinin değerlendirilmesiyle veya ilişkisel mekân kavramıla gerçekleşebileceğini savunur. Mekân ile ilişkilendirilmeyen bir sosyal teori, aynı şekilde sosyal süreçlerle ilişkilendirilmeyen bir mekân kavramsallaştırması eksik ve yetersizdir. Okuma eylemini yanlış yönlendirebilir.

Mekânın iletişimsel dili yalnızca fiziksel muhtevasında değil hafızadaki yerinde, algıdaki imgesinde, düşüncedeki kavramında yer alır. Bireyin toplumla olan ilişkisinin ve bireyin tarih içerisindeki rolünün sosyal süreçlerle ilişkisi iki farklı imgelemle kavramsallaştırılır. Birincisi, Mills (1959)' in sözünü ettiği sosyolojik imgelem; ikincisi ise tüm görsel sanatların, grafik sanatların hâkim olduğu mekânsal imgelemdir (akt. Harvey, 1975, s. 23-24). Ancak mekânsal imgelem analitik olarak daha zor ifade edilir. Mekânın anlamı ancak belirli ilişkiler sistemi içerisinde kurulur ve bireyin içinde bulunduğu sosyal ve kültürel yapıdan bağımsız olamaz.

Kentsel mekânın üretiminde de aynı durum söz konusudur. Hem ulusun sosyal yapısı hem de iktidarın ideolojik yapısı mekânın anlamını belirleyen ilişkiler sisteminin parçalarıdır. Biçim, ölçek, üslup, konum, işlev gibi fiziksel ve eylemsel özelliklerin yanı sıra ideolojik söylemlerle de mekânsal algının oluşması sağlanır. Eco (2019:114) bu çerçevede kentsel çevrenin fiziksel olarak kullandığımız kısımdan daha çok iletişimsel açıdan değerli olan imgelemlerle yüklü olduğunu savunur.

Kentsel mekânın anlatısı görsel algıyla şekillenen anıtsallık, temsiliyet, kimlik, kamusallık gibi mekânsal tanımlara ek olarak metinsel/dilsel mesajlarla da anlam ve bağlamını kurmakta, değiştirmekte ve güçlendirmektedir. Buradaki anlatı bir yazılı metin ya da konuşmadaki anlatı gibi mekânı tanım- 
larken, onun zihinsel inşasının da şekillendirilmesini, yeniden kurgulanmasını sağlar. Mekân fiziksel yapısı, işlevi, hafızadaki yeri ve belki de daha karmaşık ve heterojen olan sosyal yapısı ile toplumla iletişim kurar.

Mekânın iletişim işlevi, mekânsal disiplinleri dil olgusu ile ortak bir paydada buluşturmaktadır. Bu ortak payda, göstergebilim (semiology) çalı̧̧ma alanın da konusu olmuştur. Göstergebilim alanı, 1900'lerin başında İsviçreli dilbilimci Saussure'in dili göstergelerden oluşan bir sistem olarak tanımlaması ve tüm diller sistemi için geçerli ortak bir yapı (structure) tezi ile şekillenmiştir. Saussure (2011)'e göre, dilin birimleri olan kelimeler birer göstergedir ve kelimelerin yazılan/konuşulan "somut" ifadesine ek olarak algılanan "soyut/kavramsal" ifadeleri vardır. Bu gösterge biçimleri arasında kelimenin somut ifadesini "gösteren", kavramsal ifadesini ise "gösterilen" olarak tanımlamıştır.

Mimarlık göstergebilimi üzerine çalışmış olan Eco (2019, s. 19,20), gösteren ve gösterilen ilişkisini aktarırken; kullanım nesnesinin işlevinin, düz anlama sahip gösterilen; nesneye ilişkin kültürel/toplumsal olguların ise yan-anlama sahip gösterilen olduğunu ifade eder. Ancak bazı durumlarda kültürel/toplumsal olgular nesnenin işlevine dönüşür. Göstergeyi, Eco'nun varsayımsal örneği taht üzerinden tekrarlamak, kavramın mekânsal anlatısı ve ideolojik içerimini aktarmak açısından daha açıklayıcı olacaktır. İşlevi simgesel olan taht örneği farklı bir anlamla karşımıza çıkar. Aslında bir oturma nesnesi olan tahtın kültürel gösterileni "hükümdarın oturması" hatta "haşmetidir". Diğer gösterileni olan oturma işlevi ise rahatlık ve işlevsellik açısından değerlendirildiğinde daha dolaysızdır. Bu durumda tahtın işlevi oturmaktan ziyade bir hükümdarı, onun gücünü ve görkemini temsil etmektir. Eco (2019, s. 33)'nun ifadesi ile "simgesel yananlamlar, bir nesnenin toplumsal kullanım değerini... ilettikleri sürece, işlevsel anlamlar olarak ortaya çıkarlar..." Başka bir ifade ile bazı kavramların tanım değerlerinde toplumsal/kültürel anlamları, fiziksel işlevinden önce gelmektedir.

Mekânları tanımlarken kullandığımız kelimelerin de hem işlevini hem de sembolik anlamını ifade eden gösterileni vardır. Bu tanımlar mekânın türünü belirtmek için kullanılan kelimeler olabildiği gibi o mekânı isimlendirmek için kullanılan kelimeler de olabilir. Mekânın türünü tanımladığımız sokak ve bulvar kelimeleri işlevsel gösterilenle düşünülürken bazı yapıların tipolojisini tanımlarken kullandığımız $e v$ ve saray kelimeleri ilettikleri mesajla toplumsal gösterilenle düşünülmektedir. Mekânı isimlendirirken kullanılan kelimeler de anlam yüküne göre farklı gösterilenleri işaret eder; Konya Yolu, işlevi ile bu 
kente doğru giden karayolunu tarif ederken aynı yolu tanımlayan resmi isimlendirmesi olan Mevlana Bulvarı, Konya kenti ile özdeşleşmiş bir kişiyi anarak gönderme işlevi görmektedir.

İktidarın, mekânın anlam ve bağlamını fiziksel özeliklerinin yanı sıra "dil” üzerinden anlatı ve söz ile aktarması iki biçimde görülmektedir. İlki, en bilinen ve yazında birçok çalışmaya konu olmuş yer/mekân adlandırmalarıdır. Bu adlandırma coğrafi şekil, il ve ilçe ölçeğinde olabildiği gibi bu yazının konusu kapsamında ele alınan sokak, meydan, bina gibi kentsel ölçekteki yer adlandırmalarını da kapsamaktadır. İkinci biçimi ise mekânda görülen, alg1lanan ve bilinebilenin dışında "yüklenen anlamların" aktarılması ve tanımlanması ile gerçekleştirilir.

Yer isimleri doğası gereği kamusaldır (Tan, 2018, s. 64). Bu niteliğiyle kamusal belleğin parçasıdırlar. Kamusal mekân, işlev, imge ve kavramları ile kolektif belleği kurar. Kamusal bellek, bireylerin belleğinin toplamı olduğu gibi; bireysel bellek de kamusal belleğin bir parçasıdır ve kamusal bellekle birlikte şekillenir. Binalar ve yollar değişse veya yıkılsa bile meydanın, sokağın ya da bir mağazanın adı gibi bazı mekânsal izler uzun bir süre bellekte kalır, çünkü mekân, beşeri bir grubun yerle ilgili alışkanlıkları ile sadece hareketlerini değil aynı zamanda düşüncelerini de düzenler (Halbwachs, 2018, s. 166-168).

Dil ve mekânı birbirine bağlayan yer adları; sokak, meydan, bina, park gibi mekânlarla, metin, konuşma, harita, adres, katalog gibi araçlarla gerek gündelik hayatın bir parçası gerekse resmi/bürokratik alanda bir hafızayı kaydederler (Alderman, 2009, s. 181). Sokak isimleri (diğer yer isimleri gibi) geçmişi, insan hayatının sıradan ortamlarıyla birleştirir. Azaryahu (1997) resmi tarih kaydının bir biçimi olarak sokak isimlendirmelerini, siyasi bir prosedür olarak tanımlar. Ancak bu "dile gömülü" sosyal gerçekliğin inşası ve alg1 sürecinin gündelik yaşama, politik manipülasyondan yoksun görünen bir biçimde dahil edildiğini işaret etmektedir (Azaryahu, 1997, s. 479-481). Nash (1999) sembolik ya da somut ifadeler olması fark etmeksizin yer adlarınun iktidar, kültür, kimlik sorunları olduğunu ifade eder.

Azaryahu (1997, s. 479), modern kentlerde sokak adlandırmalarını; politik anlamlarla dolu, hegemonik düzen ile ilişkili ve onu destekleyen, iktidar ve otorite yapılarının içine yerleştirilmiş bir temsil olduğunu belirtmektedir. Tarihi olay ve kişiler ile anılan sokak isimlerinin sadece bir haritalama aracı olmadığını aynı zamanda "modern milliyetçilik çağının" ortak bir geçmiş duygusunun üretim biçimi ve resmi bir tarih kaydı aracı olduğunu ifade et- 
mektedir. Assmann (2015), iktidarın geçmişle kurduğu bağ ile kendine sağlam bir köken oluşturduğunu, bununla birlikte hatırlanmak için eylemlerinin anlatısının kurulması, anıtların inşası ve arşivleme ile geleceği de "gasp etiğini" ifade eder. "İktidar kendisine geriye yönelik meşruluk ve ileriye yönelik ebedilik kazandırı" (Assmann, 2015, s.79). Azaryahu (1997, s.481-482), sosyo-politik düzendeki yapısal değişikliklerin çoğunun başarılması görece zor (uzun soluklu) olsa da sokakların yeniden adlandırılmasının, siyasi değişimi insan faaliyetlerinin gündelik alanlarına sokan, insan yaşam alanı ve algisı üzerindeki etkisi hemen gerçekleşen, nispeten basit bir eylem olarak tanımlar. Gücünün, bir siyasi deklarasyon işlevi olarak yeni bir rejimin kurulduğunu ortaya koyan/öne süren ilân değerinde yattı̆̆ını vurgular.

Kentsel yer adlandırma ya da sokak isimlerinin ele alındığı çalışmaların konusunu çoğunlukla rejim ve iktidar değişimleri ile demir perde ülkeleri (eski Sovyet Rusya ve Doğu Bloğu ülkeleri) ve (Afrika, Uzak Doğu ve Güney Amerika kıtasındaki) sömürge ülkelerinin oluşturduğu görülmektedir. Belirgin bir rejim değişikliği ile yer isimlerinde toplu bir değişimin görülmesi, bu yeni mekân adlandırmasını iktidar ve mekân ilişkileri, kimlik, kültürel miras ve toplumsal hafıza üzerinden incelenmektedir. Kentsel yer adlandırma (urbanonymy), yazında genel olarak sokak/cadde isimlendirme altında ele alınmakla beraber, bu yazı kapsamında kentsel yapılı çevre ölçeğinde sokak (cadde, bulvar), meydan, bina, tesisleri kapsayan biçimde değerlendirilecektir.

\section{Kentsel Yer Adlandırmaları}

Modern öncesi kentlerde yer adları; yön veya mahiyetini bildiren, kullanıc1larının etnik köken, din hatta ticari faaliyetlerini niteleyen açıklayıcı tanımlar olarak görülmektedir. 18.yy sonrasında numerik ve alfabetik adlandırmalara ek olarak kentsel mekânlarda; tarihi olaylar, kişiler ve kavramlar hatta farklı yer isimleri kullanarak bu olguları hatırla(t)mak, itibar ve saygı göstermek amacıyla bir adlandırma sistemi oluşmuştur (David, 2013). Siyasi otoritenin bir özelliği olarak adlandırma, ilk kez Fransız Devrimi sırasında ortaya çıkmıştır. Örneğin, 1793'te "Place Louis XV" (XV. Louis Meydan1), "Place de la Revolution" (Devrim Meydanı) olarak yeniden adlandırılmıştır (daha sonra da "Place de la Concorde" oldu). Bu sembolik eylemle, monarşist geçmişin adı değiştirilerek, devrimci rejime doğrudan atıf yapılır. Fransız Devrimi, siyasi rejimdeki büyük değişikliklerin ve siyasi tarihteki kırılmaların ortak bir özelliği haline gelen sokakların yeniden adlandırılmasında bir model oluşturmuştur (Azaryahu, 1997, s. 481). 
Yer adlandırması, söz konusu mekâna bağlı olarak merkezi veya yerel yönetimin alanına giren, kamu erki tekelinde olan bir yetkidir. Yer adlandırmalarında, merkezi otorite ve bölgesel, yerel kurumlar arasındaki yetkilendirme konusu, siyasi otoritenin "kontrol etme" arzusu ile birlikte bir iktidar çatışması yaratır. Örneğin 1813'te Prusya devleti, Berlin sokak isimleri üzerindeki kontrolünü, bunları uygulamada ulusallaştırarak (nationalized) güvence altına alır ve kent yönetimi adlandırma prosedürleri üzerindeki herhangi bir resmi yetki alanından mahrum bırakılır (Azaryahu, 1997, s. 481). “Dolayısıyla sokak adlandırma, kentsel sahnenin/peyzajın nasıl temsil edileceğini belirleme gücüne kimin sahip olduğu ve bu sahnede/peyzajda kimin geçmişinin anlatılacağ 1 konusunda bir yarışma haline gelebilir." (Alderman, 2009, s. 181)

Tan (2018, s. 69) sokak adlarının, türü tanımlayan terim (generic) ve özel/belirleyici terim (specific) olmak üzere iki parçadan oluştuğunu belirtir. Tan'ın tanımından yola çıkarak genel olarak yer adlandırmalarının, belirten (specific term) ve tür adı (generic term) olmak üzere iki parçadan oluştuğu söylenebilir. Belirten; yer ismine ilişkisel (associative), yön bildiren (directional) ve anma/hatırlatma (commemorative) biçimleri ile şahsilik katan parçası olarak görülmektedir (Tan, 2018, s. 69). Bu nedenle yer adları çalışmaları belirtenin anlam içeriği üzerine yoğunlaşmıştrr.

Tablo 1. Yer adları; belirten (specific term) ve tür adı (generic term)

\begin{tabular}{ll}
\hline belirten (specific term) & tür (generic term) adı \\
\hline Atatürk & Bulvarı \\
\hline İstiklal & Caddesi \\
\hline Anayasa & Parkı \\
\hline Kızılay & Meydanı \\
\hline
\end{tabular}

Tablo 2. Yer isimlerinde belirten biçimleri

\begin{tabular}{ll}
\hline yön bildiren (directional) & Aşağı Mahalle \\
& Batıkent \\
\hline ilişkisel (associative) & Dereboyu Sokak \\
& Cami Meydanı \\
\hline anma/hatırla(t)ma (commemorative) & İsmet İnönü Bulvarı \\
& Dumlupınar Bulvarı \\
\hline
\end{tabular}

Yer isimlendirmeleri çalışmaları kapsamında pek değinilmeyen tür adının kullanım biçimi de mekânı, mekân üzerinden yeniden tanımlayarak farklı ve yeni bir anlam değerleri oluşturması açısından dikkat çekicidir. Sosyal medyada, konut projelerinde kullanılan isimlendirmeleri algı pazarlığı üzerinden mizahi biçimde eleştiren bir görselde, konut yapısının değişmediğini ancak farklı tipolojik yapı biçimleri ile yeniden tanımlandığı görülmektedir (Bkz. Şekil 1.) Başka bir ifade ile bu yer isimlendirmesi örneğinde tür adındaki ile 
emlak piyasası arasındaki ilişki bakımından toplum üzerinde nasıl bir algı oluşturulduğu ifade edilmektedir. Bu görsel, bir pazarlama stratejisi olarak yer isimlerinde mekânsal tipolojik terimin kullanımını ele almakta; yer isimlerinde kullanılan farklı mekân türü isimlerinin sosyal, ideolojik, ekonomik algilar oluşturmak için kullanılabildiğini örneklemektedir.

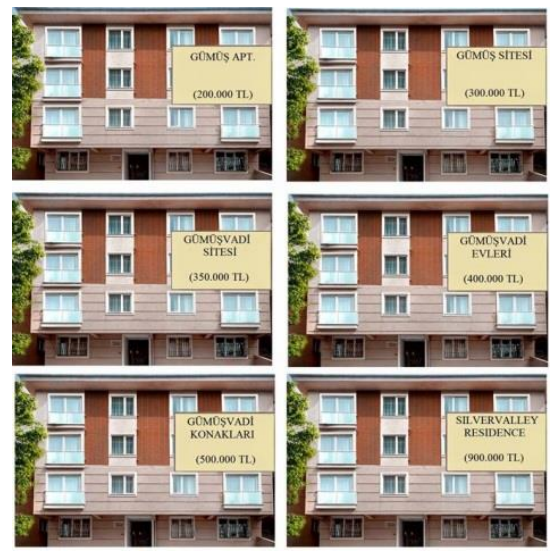

- Gümüş Apt. (200.000TL)

- Gümüş Sitesi (300.000TL)

- Gümüş Vadi Konutları (350.000TL)

- Gümüş Vadi Evleri (400.000TL)

- Gümüş Vadi Konakları (500.000TL)

- Silver Valley Residence (900.000TL)

Şekil 1. Konut projesi isimleri ve emlak piyasası ilişkisini mizahi olarak ele alan tweet görseli (Sami, 2016).

\section{Kolektif Bellek ve Temsil Mekânları açısından Yer İsimleri}

İktidarların farklı ideolojilerini gündelik kullanıma mekân adları ile sokması sıkça rastlanan ve tartı̧malara konu olan bir siyasi pratiktir. Bu uygulamanın örnekleri isimlendirme ve isim değişikliklerinde, belirten (specific term) ve tür adı (generic term) kullanımı ile iki durum üzerinden ele alınacak; her iki durum için Türkiye'de güncel yer isimlendirme örnekleri incelenecektir.

\section{Anma, Hatırla(t)ma ve Unut(tur)ma:}

Daha önce de aktarıldığı gibi yer adlarında "belirten"; ilişkisel (associative), yön bildiren (directional) ve anma/hatırlatma (commemorative) biçimleri ile şahsilik katan parça olarak tanımlanmaktadır. Ancak ideoloji ve yer adları ilişkisinde öne çıkan belirten biçimi kişi, olay, tarih, yer, kavram gibi anma/hatırlatma (commemorative) içeren kullanımlardır. Bu kullanımlar sadece cadde, sokak, bulvar, meydan, park gibi yol ve açık alanlarda değil havaalanı, okul, hastane, spor ve kültür tesisleri gibi yapılarda da karşımıza çıkmaktadır.

Modern öncesi yer isimlerinde mesleki, toplumsal, ticari, mekânsal kullanımları ile ilişkisellik ve yer, yön tanımlama kullanımları çoğunlukta olup, 
anma/hatırlama amaciyla kullanılan isimler genellikle hükümdar ve soyunun ya da yeri/binayı yaptıranın ismi ile anıldığı bir nevi aidiyet/sahiplik gösteren örneklerle kısıtlıdır. Ülkemiz tarihinde yer isimlerinde ilişkisellik ve yön bildirmeye At Pazarı, Baklacı Mahallesi, Çıkrıkçılar Yokuşu, Hisarönü, Cami Meydanı gibi örnekler verilebilir. Buna ek olarak Boyacı Ali Mahallesi, Hallac Mahmud Mahallesi gibi isimlendirmeler kişi ismiyle anılmakla birlikte aslında ilişkisellik temelinde kullanılan isimler olduğu söylenebilir. Osmanlı dönemi Anadolu şehirlerinde mahalleler; cami veya mescit gibi bir dini yapının etrafında toplanan hanelerden oluşmuş, bu nedenle cami veya mescidin adı aynı zamanda mahallenin adı haline gelmiştir. Cami veya mescitlerin ise inşa ettiren kişinin adını taşıması sebebiyle bu mahalleler kişi adından çok aslında dini yapının adını taşımaktadır (Tamur, 2010, s. 61). Selimiye, Süleymaniye, Aziziye, Hamidiye isimlerinin cami, kışla gibi yapılar ve mahalle gibi yer isimlerinde hükümdar ve soyunu anma, hatırlama gibi amaçlarla kullanılmıştır.

Cumhuriyet döneminde ise modern toplum ve ulusun inşası yer adlarına yansımıştır. Cumhuriyet' in ilanı ile ülke genelinde başlatılan imar çalışmaları ile kentlerin planlanması süreci başlamıştır. Yeni kentler, modern bir toplum kurgusuna göre inşa edilirken yeni rejimi simgeleyen kavramlar da bu yeni mekânların tanımlanması için kullanılmıştır. Büyük, küçük tüm kentlerde benzer ilkelerle düzenlenen kentsel alanlarda; bulvar, meydan, mahalle ve okullarda "Gazi" ve “Cumhuriyet" adlarının kullanıldığı (Batur, 1998, s. 215) görülmektedir. Bununla birlikte Halkevi, Sümerbank, Etibank gibi kurumların adına yansıyan ifadelerde ideolojinin üzerine kurulduğu değerler veya kendini tanımladığı tarihi sürekliliğe gönderme yapılmaktadır. Başkent Ankara'nın ilk plan çalışması olan Lörcher Planı́nda da bugünkü adıyla Kızılay (15 Temmuz Kızılay Milli İrade) Meydanı olarak anılan alanın Cumhuriyet Meydanı (sonrasında Kurtuluş Meydanı) olarak adlandırılmış olduğu görülmektedir (Cengizkan, 2004).

Lörcher Planının uygulamaya konul(a)maması üzerine bu çalışmayı altlık olarak kullanan Jansen Planında, Lörcher' in belirlediği Sıhhiye Meydanı, Lozan Meydanı gibi kentsel mekân adlarının korunduğu ancak birçok meydan ve sokak adında değişimin olduğu görülmektedir (Cengizkan, 2004, s. 123) (Bkz. Tablo 3). Cengizkan, sokak adlandırmalarındaki bu değişimin kentsel mekân kurgusunda da anlamsal kayma/yamulmayla sonuçlandığı ifade etmektedir. Kızılay bölgesindeki kentsel mekân adlarının belirlenmesinde Cumhuriyet ve kavramları ile rejimin kurucusu önder ve öncü kadroları için 
"şükran duygularının ifade edilmesi" gerekçesine dayandığını belirtmektedir. Ancak 1950'lerde yine bu bölgede değiştirilen kentsel mekân adlarının ideolojik olarak "daha tutucu (muhafazakar) bir politik döneme geçmenin yansıması" (Cengizkan, 2017, s. 237), "yönetimin daha statüko çizgisine kaydığını imgeleyen göstergeler" (Cengizkan, 2004, s. 123) olarak nitelendirmektedir.

Tablo 3. Başkent Ankara'da değiş̧tirilen kent mekânı isimleri. Cengizkan (2017, s. 238)'dan uyarlanarak güncellenmiştir.

\begin{tabular}{|c|c|c|}
\hline İlk İsimlendirme & Sonraki İsim(ler) & Bugünkü İsim \\
\hline Cumhuriyet M. & $\begin{array}{l}\text { Kurtuluş Meydanı / Hürriyet } \\
\text { Meydanı Kızılay Meydanı* }\end{array}$ & $\begin{array}{l}15 \text { Temmuz Kızılay Milli İrade } \\
\text { Meydanı }\end{array}$ \\
\hline Taşhan* & Millet Meydanı & Ulus Meydanı \\
\hline Tandoğan Meydanı & & Anadolu Meydanı \\
\hline Kazım Paşa (Özalp) Cad. & & Ziya Gökalp Cad. \\
\hline Dikmen Cad. & & Necati Bey Cad. \\
\hline Dikmen Cad. & & Milli Müdafaa Cad. \\
\hline Manevra Rampası & & Gazi M. Kemal Blv. \\
\hline Necati Bey Cad. & & Gazi M. Kemal Blv. \\
\hline $\begin{array}{l}\text { Millet (Ulus) Cad. } \\
\text { (Kızılay'dan Kuzeye) }\end{array}$ & Gazi M. Kemal Cad. & Atatürk (Uranı) Bulvarı \\
\hline $\begin{array}{l}\text { Çankaya Cad. } \\
\text { (Kızılay'dan Güneye) }\end{array}$ & & Atatürk Bulvarı \\
\hline Devrim Sk. & & İnkılap Sk. I \\
\hline Sedd-ül Bahr Sk. & & İnkılap Sk. II \\
\hline İsmet Paşa Cad. & & Mithatpaşa Cad. \\
\hline Abdülhalik Bey (Renda) Sk. & Adakale Sk. & Dr. Mediha Eldem Sk. \\
\hline Dr. Refik Bey (Saydam) Sk. & & Sağlık Sk. \\
\hline İstasyon/Ankara Garı Meydanı* & & Demokrasi Meydanı \\
\hline İtfaiye / Hergelen* Meydanı & Opera Meydanı & Erbakan Meydanı \\
\hline
\end{tabular}

${ }^{*}$ Bu yer isimleri resmi bir karara bağlı olmayıp, kolektif isimlendirmelerdir.

Başkent Ankara'da kentsel mekândaki yoğun isim değişiklikleri 1950'li dönemle sınırlı kalmamıştır. 90'lı yıllar sonrası, kentsel mekânda Ankara Büyükşehir Belediye'si tarafından yoğun biçimde isim değişikliği gerçekleştirilmiştir. Özkan ve Yoloğlu, 2005 yılında yayınlanan çalışmada, 1994-2005 yılları arasından Ankara'da yapılan 552 adet sokak/cadde isimlendirmesinin 235 adetinin (\%42,6), toplumsal belleğe müdahale açısından önemi daha belirgin olan "isim değişikliği/yeniden isimlendirme" (isimden veya numaradan isime değişim) olduğunu ortaya koymuştur. Üstelik bu değişimlerin de \%50,7'si Refah Partili Melih Gökçek'in Ankara Büyükşehir Belediye (ABB) Başkanı olmasını takip eden ilk iki yılda (1994-95) gerçekleşmiştir.

2013-2020 arasında Ankara'da kent mekânı isimlendirmeleri, ABB internet sitesinde bulunan veriler doğrultusunda meydan, bulvar, cadde ve sokak 
isimleri üzerinden ele alınmıştır ${ }^{5}$. Bu doğrultuda ilk isimlendirme ve isim değişiklikleri üzerinden sayılar incelendiğinde numara ile ilk isimlendirmenin $\% 75,68$ ile en yüksek oranda, isimden isime değişim ise $\% 1,34$ ile oldukça düşük bir oranda olduğu görülmektedir (Bkz. EK Tablo 4).

1994-2005 yılları arasında yapılan analizle farklı yönde bir sayısal sonuç karşımıza çıkmakla birlikte, 2013-2020 yılları arasında yer isimlendirmeleri (ilk isimlendirme ve değişiklikler) sayısal verilerden ziyade kullanılan isimlerin anlam yükü ile Türk-İslam medeniyetleri ve kültürünü temsil eden göndermelerin ağırlığı görülmektedir. 1994-2005 yılları arasında sokak isimlendirmelerine müdahale, yeniden isimlendirme ile mevcut olanı yıkma/bozma ile öne çıkarken 2013-2020 arasında yeni bir anlam kurma açısından daha belirgindir.

$\mathrm{Bu}$ isimlerin nitelikleri ana başlıkları kişi isimleri, yer isimleri, kavramlar, doğa çağrışımlı isimler ve gruplandırılamayan diğer örnekler olarak tanımlanabilir. Bu ana başlıklarda Türk-İslam medeniyeti ve tarihine referans veren yer isimlendirmelerinin; bilim, sanat, demokrasi ve özgürlükle ilişkili isimlendirmelere göre baskınlığı fark edilmektedir (Bkz. EK Tablo 5). Bu yer isimlendirmeleri, kentsel mekânda Türk-İslam medeniyeti ve tarihi ile bir bağ kurulmakta, yeni bir anlam değeri ve hafıza oluşmaktadır. Yerel yönetim, siyasi meşruiyetini kaynağı olarak gördüğü tarih ve kavramları, kentsel mekân isimleri aracıllğıyla günlük yaşamla buluşturarak her gün herkese ulaşabilen bir hatırlatma ve bildiri sunmaktadır.

Buna ek olarak güncel siyasi içerimli isimlendirmeler de kamuoyunun dikkatini çekmiştir. 9 Temmuz 2018'de Başbakanlık görevi biten Binalı Yıldırım'ın ismi 13 Temmuz 2018 tarihli ABB Meclis kararı ile bulvar ve cadde ismi olarak verilmiştir. ABB Başkanlığı görev süresi içinde iki cadde "Melih Gökçek" olarak isimlendirilmiştir. 11 Şubat 2015 tarihli kararla Beştepe Mahallesinde bulunan "Zübeyde Hanım Sokağı" ismi "Cumhurbaşkanlığı Caddesi" olarak değiştirilmiş, daha sonra yine Beştepe'de başka bir cadde "Zübeyde Hanım" olarak isimlendirilmiştir (ABB, t.y.).

Ankara'da yakın zamanlı ismi değiştirilen Kızılay Meydanı ve Gar/İstasyon Meydanı ilişkisel yer adlandırmalarına örnektir. Resmi kayıtlarda "Hürriyet Meydanı" olarak geçen Kızılay Meydanı da, resmi bir isimlendirmesi

\footnotetext{
5 Özkan ve Yoloğlu'nun çalışmasını kapsayan tarih aralığında (1994-2005) isim niteliği ile ilk isimlendirme 90 adet $(\% 16,3)$ olarak belirtilmiştir. Bugün ABB resmi internet verilerinde 2013-2020 tarih aralığındaki sokak-cadde isim değişikliklerine ulaşılabilmektedir. Yerel yönetimdeki siyasi değişimle 1994-1995 yıllarında yoğun biçimde gerçekleşen isimlendirme faaliyetlerinde ilk isimlendirmelerin "anlam içeriği" bilinmemekle beraber, bugün ulaşılan veriler içinde ilk isimlendirmeler de yeni bir hafiza kurma kapsamında değerlendirmeye alınmıştır.
} 
olmayan Gar/İstasyon Meydanı da kolektif hafızanın ürünü olan isimlendirmelerdir. Bu mekânların yeni isimleri burada yaşanan toplumsal olayları hatırlatma amacı taşımaktadır. Türkiye'de 15 Temmuz'da yaşanılan askeri darbe girişiminin ardından birçok kentte olayların merkezi sayılan İstanbulBoğaziçi Köprüsü ve Ankara-Kızılay Meydanı başta olmak üzere birçok yol (sokak, cadde, bulvar), meydan, durak ve parkın ismi değiştirilmiştir (Gazeteduvar, 2017; HaberSol, 2017; Hürriyet, 2016; Hürriyet, 2018). Kızılay Meydanı'nın, Ankara Belediye Meclisi kararı ile "15 Temmuz Kızılay Milli İrade Meydanı" olarak yeniden adlandırılması toplumsal belleğe müdahale yönüyle bazı tepkileri beraberinde getirmiştir. Mimarlar Odası (MO) Ankara Şubesi bu yer ismi değişikliğine ilişkin yayınladığı basın açıklamasında "toplumsal yaşamın karşılaşma ve buluşma alanı, kent demokrasisinin yaşama alanı ve zora düşürüldüğü durumlarda direnme alanları" olan sokak, meydan, anıt ve yapıların bellek mekânları olarak tarihe tanıklığı, simgeselliği, anı birikimi ile bulundukları alanı isimlendirdiklerini belirtmiştir. Kent kimliğinin ve kültürünün sürekliliğinin sağlanması ve kuşaklardan kuşaklara aktarılan mekânsal izlerin oluşmasının toplumsal hafıza ile mümkün olduğu ifade edilmiştir (Mimarlar Odası-Ankara, 2016).

Aslında Kızılay Meydanı ve semt olarak Kızılay olarak anılan alanın farklı resmi isimleri vardır. Kızılay olarak anılan alan Devlet, Namık Kemal, Meşrutiyet, Cumhuriyet ve Kızılay Mahallerinden oluşmaktadır. Kızılay meydanının resmi ismi ise 8 Ağustos 2018 tarihli ABB Meclisi isim değişikliği kararında da görüldüğü üzere aslında "Hürriyet Meydanı"dır. Bugün Kız1lay olarak bilinen ve geniş bir mahalleler bütünün kapsayan bu alan Ankara'nın planlandığı ve kurulduğu yıllarda neredeyse bomboş bir arazidir. Yeni plan kararları ile bu alanda (Kızılay' da) kurulacak yeni yerleşim "Yenişehir" olarak anılmaktaydı. 1920'li yıllarda bu alanı tanımlayacak kamusal nitelikte ya da ölçekte tek mekân, Su Perili heykel çevresindeki havuzun bulunduğu bahçedir. Bu dönemde alanın "Havuzbaşı" olarak anılması 20 yy. öncesi kamusal alanların genelde onu tanımlayan yapılarla ya da faaliyetlerle anılmasının geleneksel alışkanlıklar doğrultusunda sürdürülmesi olmalıdır. 1929 yılında Kızılay Binası inşasından bir süre sonra heykelin taşınması ve havuzun kaldırılması ile meydanı tanımlayan ölçekteki mekân görevi, Kızılay Binasına devredilmiş olur.

Heykel ve havuzsuz kalan park, Kızılay binası ile bir kurum bahçesi niteliği alarak Kızılay Parkına dönüşür. Zaman içinde fiziksel özelliklerini de yitiren parkla beraber kurum binası da 1979 'da yeni bir yapı yapılmak üzere yıkılır (Çağlar, Uludağ ve Aksu, 2006). Fiziksel yapısı değişen bu meydanda 
"kentlinin meydanı deneyimleme biçimlerinin değişmesi, sosyal pratiklerin ve yerin anlamının değişmesine neden olmuştur... Ancak meydanın değişmesi süresince oluşan farklı anlam katmanlarından kentsel çevrenin sosyal ve fiziksel işaretlerini, kodlarını okuyabilir, sosyal ve kentsel yapıdaki dönüşümleri ve kentsel peyzaja yazılmış olan güç ve ideoloji ilişkilerini anlayıp ortaya çıarabiliriz" (Çağlar, Uludağ, ve Aksu, 2006). Çağlar, Uludağ ve Aksu (2006)'nun ifadesi ile meydanın "öyküsünü" okumamızı sağlayan "anlam katmanlarından" birinin de toplumsal olarak biçimlenmiş olan adı olduğunu söyleyebiliriz.

Resmi adı "Hürriyet Meydanı" olarak belirlenmiş ve Kızılay Binası yıkılmış olmasına rağmen meydanı bina ile tanımlayan kolektif hafızada bu alan artık "Kızılay Meydanı"dır. Üstelik sadece günlük dilde değil; basın, akademik çalışmalar, mimarlık ve kent otoritelerince de "Kızılay Meydanı"dır. Bu nedenle aslında resmi olarak Hürriyet Meydanı'nın ismi, kolektif bellekte K1zılay Meydanı'nın ismi değiştirilmiştir ve yeni resmi isme Kızılay kelimesinin dâhil edilmesi ile Kızılay ismi, amaç bu olmasa da tescil edilmiş olur.

Turan ve Yalçıner Ercoşkun (2017), meydanlardaki isim değişikliklerinin kent belleğine etkisini bir anket çalışması ile Ankara örneği üzerinden Kızılay, Tandoğan ve Gar Meydanı ile inceledikleri çalışmada, Mimarlar Odası Ankara Şubesinin basın açıklamasında da belirtildiği gibi bu isimlerin toplumsal hafıza tarafından benimsenmekte güçlük çekildiğini ortaya koymuşlardır. Bu araştırmaya göre Kızılay Meydanı'nın yeni ismini doğru bilenlerin oranı \%25 olarak tespit edilmiştir (Turan ve Yalçıner Ercoşkun, 2017, s. 62-66).

Araştırmanın yapıldığı tarih itibariyle, isim değişikliği üzerinden geçen kısa süre toplumsal bellek üzerinde etkisini göstermesi bakımından kısa bir zaman dilimi olabilir. Yedi kelimeden oluşan adlandırma, günlük kullanımda yer ismi olarak uzun olduğu söylenebilir. Günlük konuşma dili ve adres yazımı gibi öznel kullanımlara yansımaları henüz belirgin olmasa da yerel yönetimin otobüs, dolmuş güzergâh/hat isimleri ve metro durakları, tabelaları ile bu isim değişikliklerini günlük hayata hemen yansıtmıştır. Üstelik bu sadece tabelalar ile görsel biçimde değil, otobüs ve metrolarda bant kayd1 ile güzergâh/durak isminin sürekli tekrarı ile işitsel olarak günlük hayatın akışında yer almaktadır. Ancak kullanımda Kızılay ifadesi yerine, kısaltma yapılarak, (otobüs hatlarında da kullanılan biçimiyle) "15 Temmuz" ya da "Milli İrade" gibi tanımların da halen tercih edilmediği görülmektedir.

Turan ve Yalçıner Ercoşkun'un bu çalışmasında Gar Meydanı'nın yeni ismini doğru bilenler ise sadece \%9 oranındadır. 10 Ekim 2015 tarihinde Ankara Garı önünde bulunan meydanda düzenlenen Barış Mitingine yönelik 
gerçekleştirilen terör saldırısından sonra mitingin adı ve amacıyla özdeş olması nedeniyle, daha önce resmi bir adı bulunmayan bu alanın "Barış ve Demokrasi Meydanı" olarak anılması önerilmiştir. Fakat ABB Meclisi tarafından sadece "Demokrasi Meydanı" olarak isimlendirilmesi de "Barış" kelimesini kullanmaktan kaçınma yönünde iddialarla tartışma konusu yaratmıştır (Diken, 2015; NTV, 2015; Yeni Şafak, 2015).

Tandoğan Meydanı isim değişikliği de "karşı temsil mekânı" (Ghulyan, 2017) olarak meydanın (dil üzerinden) yeniden kurgulanmasına bir örnektir. Meydana adını veren Nevzat Tandoğan, Başkent Ankara'da 18 yıl valilik ve belediye başkanlığı görevini yürütmüştür. Tandoğan'ın ismi, Ankara'ya yaptığı hizmet nedeniyle 1946 yılında vefatının ardından bu meydana verilmiştir. Ancak Nevzat Tandoğan'ın, Anadolu halkını hakir ve ikinci sınıf vatandaş olarak gördüğü gerekçesi ile onun isminin demokratik değerlerle bağdaşmadığı bu nedenle Meydanın isminin "Bağımsızlık, Cumhuriyet ve Demokrasi" olarak değiştirilmesi talep edilmiştir (Ghulyan, 2019, s. 133). Meydanın ismi tamamen değiştirilmemiş, ancak 2012 yılında sadece Tandoğan olarak yenilenmiştir. Toplumun, Nevzat Tandoğan ile doğrudan ilişkilendirmeyeceği muğlak bir anma biçimiyle bir kesim tarafından ortaya konan rahatsızlığı da çözüme bağlamak amacıyla bir düzenleme yapılmıştır.

Ancak Tandoğan isminin oluşturduğu iddia edilen huzursuzluk, 2015 y1lında daha sert biçimde tekrar gündeme gelmiştir. Bu kez Tandoğan'ın Anadolu halkını hakaret ederek aşağıladığı gerekçesiyle, meydanın ismi "Anadolu" olarak değiştirilmiştir. Ghulyan (2019, s. 134; 2017, s. 297) bu değişimi yerel yönetimin (ve belediye meclis çoğunluğunun) siyasi söylemini “halktan olma" vurgusu ile mekân ismine yansıttığını belirtmektedir. Bu yolla mekân, Anadolu halkını "aşağılayan" "Tandoğan"ın temsil ettiği bir taraf ile "halktan olan" ve "Anadolu" ile temsil edilen bir diğer taraf arasında mekânsal bir söylemin oluşturulduğunu ifade etmektedir. Ayrıca yazar, bu isim değişikliğinin tek sebebinin Nevzat Tandoğan'ın şahsına ilişkin olmadığını, 2007 y1lında Meydan'da gerçekleşen "Cumhuriyet Mitingi" ile toplumsal bellekte üretilen mekân temsilini "bastırma, unutturma çabası" olduğu yorumunda bulunmaktadır (Ghulyan, 2017, s.299). Tandoğan Meydanı, Cumhuriyet tarihinde mekânsal pratikler açısından birçok kesime ev sahipliği yapmış bir yerdir. Bastırma ve unutturmanın yanı sıra, Ankara'nın miting alanı haline gelen Meydan'da düzenlenecek yeni toplantıları "Anadolu" Mitingi olarak anarak mekânsal pratikler üzerinden yeni bir hafıza kurulmaya çalışılacaktır. 
Güncel yer isimlendirme faaliyetleri, Ankara kenti ve sokak/cadde ölçeğinde kalmamıştır. Türkiye'de yer isimleri ve politika mekân ilişkisi; literatürde de farklı çalışmalara konu olmuş örnekler incelenmiştir. Çoban (2013) politik bir araç olarak ele aldığı yer isimlendirmelerini Türkiye'de önemli siyasi dönüşümler açısından Osmanlı dönemine uzanan yer isimlerinin Türkçeleştirilmesi, 12 Eylül sonrası ve 2000'li yıllar-AKP dönemi olarak üç ana kategoride incelemiş̧tir. Çalışma kapsamında yer isimleri örnekleri köy, kasaba ve mahalle gibi yerleşim yerlerinden okul, kışla, havaalanı, üniversite, kurum isimlendirmeleri ve isim değişikliklerini içermektedir. Özberk (2018) Türkiye'de politik dinamiklerin mekânsal semiyotiğe yansımasını Nevşehir kenti üzerinden okurken genel olarak incelenen sokak (cadde, bulvar vb.), park ve mahalle isimlerine ek olarak okul ve üniversite isimlerinde öne çıkan ideolojik tercihlere vurgu yapmaktadır. Yer isimlerinin siyasi yapıyla gösterdiği değişikliği Niğde kent merkezi ile ele alan Kara (2012) sokak, kavşak (ve meydan), park ve bahçeler ile uydu kent isimlerini incelemiştir. Günal (2012) ise çalışmasında Batman kenti cadde adlarını, yerel yönetimde iki farklı siyasi kimliğe sahip partinin (Refah Partisi ve Halkın Demokrasi Partisi) yer isimlerini bir siyasi mücadele alanı haline getirmesi kapsamında ele almıştır.

Bununla birlikte kamuoyunda da özellikle büyük ölçekli projeler ile temsil mekânlarının isimlendirmeleri konusunda tartışmalar ve eleştireler görülmektedir. Bu örneklerle sinırla kalmamakla birlikte; İtfaiye veya Hergele Meydanı olarak da bilinen Opera Meydanı'nın bu alanda yapılan yeni cami inşası sonrası Erbakan Meydanı olarak yeniden isimlendirilmesi, ODTÜ arazisinin kullanılmasıyla gündeme gelen araç yolunun 1071 Malazgirt Bulvarı olarak adlandırılması, İstanbul Boğazı'nda yapılan 3. Köprüye 'Yavuz Sultan Selim' adının verilmesi (Arkitera, 2013; T24, 2013), İzmir'de 1937 yılında resmi kararla Atatürk Meydanı olarak isimlendirilen ancak kolektif hafızada Konak Meydanı olarak işaretlenmiş alanın 15 Temmuz Demokrasi ve Şehitler Meydanı olarak değiştirilmesi talebi ve sonrasında "Atatürk Konak Meydanı" olarak resmi isim ve kolektif tanımın birleştirilmesi (Hürriyet, 2016), Rize Fındıklı'da Millet Bahçesi'nin adını 100. Yıl Atatürk Parkı olarak değiştirmesi ve bu nedenle açlan soruşturma (Akduman, 2020), yıkılarak yerine yenisi inşa edilen İstanbul Atatürk Kültür Merkezi (AKM) ve yeni (3.) havalimanın yapılması ile işlevsiz kalan İstanbul Atatürk Havalimanı da (Bayer, 2017) yer isimlendirmesi tartışmalarına konu olmuştur.

Bu tartışmalar çerçevesinde kültür merkezi ve havalimanı binalarının yıkılması/işlevsizleştirilmesinde, mekân isimlerinde bulunan "Atatürk" ifadesinin kullanım dışı bırakılmasının da amaçlandığı iddia edilmiştir (Çaralan, 
2018, 2018; Gazeteport, 2015; T24). "Atatürk" adının kullanımı konusunda farklı bir tartışma da yeni Cumhurbaşkanlığı Yerleşkesinin inşa edildiği Atatürk Orman Çiftliği (AOÇ) alanının artık semt adı ile "Beştepe" olarak anılmasıdır. Batuman (2015), bir yandan AOÇ adlandırmasın iktidarca tercih edilmemesini "işgal edilen mevkiinin" yeniden tanımlanması üzerinden yorumlamakta, diğer yandan bu alanın zorlama biçimde iliştirilen semt ismi ile "Beştepe" olarak anılmasının, yerleşkenin sembolik iddiasını zayıflattığını ifade etmektedir. "'Çankaya Köşkü' örneğindeki gibi mevki ile kurulan bir isim değildir zira söz konusu olan; 'Beştepe'deki Cumhurbaşkanlığı Sarayı'dır... iktidar temsili olma iddiasındaki yapı, temelindeki gayrimeşru işgal yüzünden kendisinden daha zayıf nirengi noktalarına tutunmaya çalışır." (Batuman, 2015)

Atatürk adıyla anılan bu mekânlar önemli temsil mekânlarıdır; Atatürk Havalimanı yurtdışı uçuşlarla dünyaya açılan bir kapı, Taksim Meydanı'ndaki AKM kamusal bir cephe, AOÇ ise erken Cumhuriyet döneminin kalkınma ve planlama vizyonunun simgesidir. Recep Tayyip Erdoğan'ın konuşmalarında "Atatürk" ü anarken "Gazi Mustafa Kemal" olarak ifade etmesi, "Atatürk" adını kullanmaktan kaçınması olarak yorumlanmakta (Gürsel, 2019; Yetkin, 2017), mekân isimleri üzerinden yürütülen tartışmalar da bu iddiaya dayanmaktadır. Cumhuriyet Gazetesi yazarı Tayfun Atay (2015) konuya ilişkin olarak kaleme aldığı köşe yazısında [Atatürk adını kullanmaktan kaçınıyor] “Çünkü İstiklâl Harbi'nde Kuva'yı Milliye'nin komutanı olan Mustafa Kemal'i kabul ediyor. Ama ssrarlı bir Batılılaşma politikası izleyerek ülkeden İslâm'ın köklerini koparmaya çalıştığı düşünülen Atatürk'ü kabul etmiyor..." ifadeleri ile yorumlamıştır. Atatürk isminin kullanılmaması genel olarak kamuoyunda dikkat çeken bir konu haline gelmiş hatta Erdoğan bu konuda bir açıklamada bulunmuştur 6 . Atatürk isminin yer/bina/kurum, isim/tanımında kullanılması ya da kullanılmaması/değiştirilmesi kamuoyu tarafından, iktidarın bu isme yüklediği düşünülen anlam yükü bakımından değerlendirilmektedir.

Yeni yer isimlendirmelerinde veya isim değişikliklerinde kullanılan ifade ve kavramlar anlam yükü açısından veya hafızada yer etmiş olan eski isimler ve deneyimler sebebiyle hemen kabul görmezler. İktidarın günlük yaşama

\footnotetext{
62017 yılı 10 Kasım töreninde yapılan konuşmadan; “...Ülkemizde eskiden beri hep bir Atatürk ve Atatürkçülük tartışması yaşanmaktadır... Milletimizin Gazi’ye hürmeti sonsuzdur, milletimizin Mustafa’ya saygısında en küçük bir tereddüt yoktur. Milletimizin Kemal'le de en küçük bir sorunu bulunmuyor. Milletimizin soyadı olarak kendisine verdiği Atatürk konusunda da hiçbir sıkıntısı olmadığını gayet iyi biliyoruz...". (TCCB, 2017)
} 
yer isimleri aracılığıyla kolayca yerleştirdiği bu imgelemlerin, gündelik yaşamda kolayca benimsenmediği hatta üstü örtülü bir direnme olgusuyla karşılaştığı görülmektedir.

\section{Mekânı Yeniden Tanımlama}

Yer adlarında, yerin niteliğini ve bu niteliğin alt türünü belirten terimsel ifadenin de (tür adı / generic term) farklı anlam yükleri ile karşımıza çıktığı örnekler bulunmaktadır. Yer adlandırmalarının genel araştırma alanından farklılaşan bu örnekler; bir mekânsal niteliği başka bir mekânın anlamına aktarmak için kullanılmaktadır. Bu durum için en belirgin örnek Amerika Birleşik Devletleri (ABD) Başkanlığının resmi ikametgâh ve çalışma makamı olan "White House" olarak gösterilebilir. Her ne kadar Türkçede Beyaz Saray olarak kullanılsa da asıl kelime çevirisi ile bu resmi konut ve ofis yapısı İngilizcede "beyaz ev" anlamındadır.

Eski Washington haritaları üzerinde, yapı Başkanlık Sarayı (President's Palace) olarak ifade edildiği görülmekle birlikte 1810 yılında kraliyetle/otokratik bir yönetimle ilgili çağrışımlardan kaçınmak amacıyla ismi Yönetici/İdare Konağ (Executive Mansion) olarak değiştirilmiştir (Bigler, 2020). Ancak neredeyse her ABD eyalet valisi için bir "yönetici/idare konağı" olduğundan, başkanının resmi makamının diğer konaklardan ayrışması için Başkan Theodore Roosevelt 1901 yılında yapı grubunun resmi adını, yapının cephe kaplaması olan beyaz-gri taşlara atıfla "White House" olarak değiştirmiştir (White House, t.y.).

Bu değişim sürecinde, yapı türünü tanımlayan ifadenin saraydan konağa, konaktan ise eve dönüştügü görülmektedir. Yapının mekânsal niteliği ise bu süreçte; ek binalar ve yenileme ile ölçek olarak büyümüş, donanım olarak ise zenginleştirilmiştir. Yapı grubunun ölçeği ve donanımı genişlerken, onu tanımlayan yapı tipolojisi teriminin anlamı daralmıştır. Saray ve konak yöneticilik vasfı ve görkemi belirten ikametgâhlar iken, ev ise aile kavramı ve sadeliği vurgular.

Aslında White House, $5109 \mathrm{~m}^{2}$ taban alanı ile günümüzde birçok başkanlık sarayı içinde görece küçük ölçekli bir yapıdır (Arkitera, 2014). Ancak elbette zihinde canlanan "ev" kavramından farklı olduğu da bir gerçektir. Başkanlık konutunun aile kavramını çağrıştıran biçimde ev olarak anılması, başkanların "ev" içinde ailesi ile birlikte günlük hayatından kareler basına sunularak görsel medya ile de desteklenmektedir (Şekil 2). 
Ayrıca White House, 20.yy'a kadar günlük ziyaretlerin, kamuya açık davetlerin yapılabildiği bir mekân iken, gerek yoğunluk gerekse güvenlik sebepleri ile kamuya açık olma durumu günümüzde daha kontrollü biçimde sürdürülmektedir. Aile kavramı ve ikametgahta halkın konuk edilmesi ile ev tanımı bütünleştirilmekte, bu sayede devlet başkanı üstünlük vasıflarından arındırılmaktadır. Bununla birlikte White House'un "devletin evi" olarak zihinlerde yer etmesi için günlük hayata kolayca dâhil olan yirmi Amerikan Doları banknotu üstüne de yerleştirilmiştir (Şekil 3).
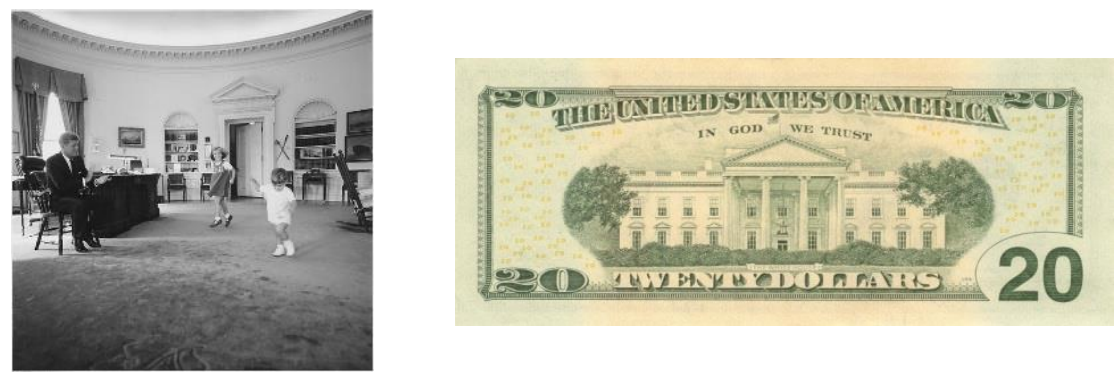

Şekil 2. (Solda) JFK, White House başkanlık ofisi/oval ofiste çocukları ile oynarken (Stoughton C. , 1962)

Şekil 3. (Sağda) 20 ABD Doları banknotu (Wikipedia Commons)

Bazı ülkelerde cumhurbaşkanlığı konut ve ofis/çalışma alanı aynı mahalde yer alırken bu iki işlev ayrı mahallerde/binalarda ve alanlarda da bulunabilmektedir. Bu çalışma ve ikametgâh mahalleri; genel olarak saray anlamına gelen kelimelerle tanımlandığı gibi yapı tipolojisi olarak büyük ölçek, heybet, anıtsallık çağrıştıran villa (K.Makedonya-Villa Vodno), köşk/ (Liberya, The Executive Mansion ve Türkiye, Pembe Köşk-eski) ve kale (Prag Kalesi ile Letonya-Riga Kalesi) olarak ifade edildiği az sayıda örnekte görülmektedir. Saray kelimesi kadar, birçok örnekte (Costa Rica-Casa Presidencial, Kenya-State House, Ghana-Jubilee House gibi) ev kelimesinin kullanıldığı da görülmekte$\operatorname{dir}^{7}$.

Saray kelimesinin yer adı tanımında kullanılması farklı kamu hizmet yapılarında da görülmektedir. Bazı anlatımlarda 'Adliye Binası' olarak da kul-

\footnotetext{
${ }^{7}$ Bu örnekler dışında devlet başkanları yaşam alanı ve/veya çalışma makamları için bina, ofis, ikametgah, kompleks/tesis, kule, merkez (headquarters) gibi yapı tipolojisini tanımlamaya özgü ve anlamsal yük bakımından tarafsız az sayıda kullanımlar da bulunmaktadır. Ancak tür adı yanında; Hükümet/Devlet Evi, Ulusal Saray, Ulus(un) Sarayı, Halk Sarayı, Devrim Sarayı, Halk Evi gibi ulus devlete, demokratik kavramlara gönderme yapan ön adlar (belirten) kullanarak ev ya da saray olarak bu binanın aidiyetinin burayı kullanan devlet başkanında olmadığı anlamı yüklenmiştir.
} 
lanılmakla birlikte yapıların isimlendirilmesinde sıkça rastlanılan 'Adalet Sarayı' ve 'Adliye Sarayı' kullanım biçimleri" bu yapıların "hukukun en üst mertebesinde değer görmesiyle" yorumlanmıştır (Akalın, 2013). Benzer biçimde Emniyet Sarayı, Belediye Sarayı, Kültür Sarayı gibi farklı kamu hizmet yapılarının da ölçek olarak büyüklügünü ve kurum olarak önemini ifade etmek için kullanılmaktadır. Ancak saray kelimesi yargı, emniyet, kültür vb. işlevli mekânlar için çoğu zaman olumlayıcı bir anlam katarken, Başkanlık makamları için kullanıldığında otoriter rejimleri çağrıştıran, israf ve gösterişi hatırlatan dolayısıyla yönetim tarafından istenmeyen anlamlar yüklemektedir'.

\section{Başbakanlık Hizmet Binası, Ak Saray, Cumhurbaşkanlığı Sarayı, Cumhurbaşkanlığı Külliyesi, Milletin Evi: HANGÍsi?}

Mekânı, farklı bir mekân tipolojisi üzerinden yeniden tanımlama durumuna benzer diğer bir örnek ise tarihselci üslubu, AOÇ arazisi üzerinden gelişen yargı süreci ve maliyeti ile gerek toplumsal gerekse mimarlık gündemini uzun süre meşgul eden Cumhurbaşkanlığ 1 Yerleşkesidir ${ }^{10}$. Bu yapılar grubu 2012 yılında tasarlanması ve 2013 yılında inşaata başlanması sırasında Başbakanlık Hizmet Binası olarak projelendirilmiştir. Ancak 2014 yılında yapılan Cumhurbaşkanlığı seçimi sonrasında, yerleşke ve yapılar grubunun tamamı bir gün içinde işlev değiştirerek Cumhurbaşkanlığ 1 Sarayı (sonrasında Külliyesi olarak isimlendirilmiştir) haline gelmiştir. Sadece isim değişikliği ile binanın işlevi de değişmiş midir yoksa Gür ve Altan (2015)'ın da ifade ettiği gibi Başbakanlık Hizmet Binası yapılırken zaten "ileride geçilmesi hedeflenen başkanlık rejiminin mekânı olarak öngörüldükleri de söylenebilir" mi? Bu sorunun cevabı halen muallaktır. Aynı muallaklığın, mekânı tanımlayan,

\footnotetext{
8 Türkçede kullanılan 'Adalet Sarayı' ifadesi farklı dillerde de benzer karşılığı ile (Courthouse yerine) örneğin İngilizcede Justice Palace, Fransızcada Palais de Justice, İspanyolcada Palacio de Justica şeklinde kullanılmaktadır. Bu ifadeler bazen adliyeleri bazen de yüksek mahkeme binalarını ifade etmektedir.

${ }^{9}$ Diğer kamu yapılarında "saray" kelimesinin, tarihi referansı nedeniyle olumsuz değerlendirildiği durumlarda vardır. Bugün AKM (Atatürk Kültür Merkezi) olarak bildiğimiz yapı ilk olarak İstanbul Kültür Sarayı olarak isimlendirilmiştir. "Saray" kelimesinin anlam ve temsil olarak uygun olmadığı tartışması 2 Mayıs 1969 tarihli Cumhuriyet Gazetesinde Muhsin Ertuğrul tarafından ortaya konmuştur. Daha sonra, 1970’de yangın sonrası tadilat çalışmaları sırasında da; dönemin Kültür Bakanı Talât Sait Halman, "Cumhuriyet devrinde saray kurulmaz; bu, imparatorluk devrindeydi." açıklamasıyla yenilenen binaya 'Atatürk Kültür Merkezi' adının verildiğini açıklamıştır (Ulușahin, 2017).

${ }^{10}$ Resmi adı Cumhurbaşkanlığı Külliyesi olan yapılar grubunu tanımlarken; Gür ve Altan (2015) "saray, yerleşke, konut, köşk ve benzerleri”" için “ya büyüklük bakımından yetersiz ya da yönetim birimleri, konut, kültür yapısı ve cami gibi değişik işlevleri içerdiği için anlamsız ve uyumsuz...” kaldığını belirtmiştir. Ancak Batuman (2019, s. 253,254) "anlam yükü bakımından daha nötr olduğunu düşünerek 'Cumhurbaşkanlığı Yerleşkesi”" ifadesini kullanmayı tercih ettiğini belirtmiştir. Aynı tercihle hareket ederek, metin içinde Cumhurbaşkanlığı Külliyesi “yerleşke” olarak anılmaktadır.
} 
değişken (resmi ve gayrı resmi) adlandırmaların (hizmet binası, saray, külliye, ev) anlamsal içeriği açısından da devam ettiği görülmektedir.

İşlev değişikliği yapılan bu tesis Cumhurbaşkanlığı makamı konut ve çalışma alanı ve bağlı birimlerin ofislerinin bulunduğu idari yapılar ile cami, kongre merkezi ve kütüphaneyi de içine alan kamusal dini, sosyal, kültürel işlevlerle çok amaçlı bir yerleşke olarak inşa edilmiştir. İşlev değişikliği sonrası bu tesis ve yapılar grubu alanı için 'Ak Saray', 'Cumhurbaşkanlığı Yerleşkesi', 'Cumhurbaşkanlığı Sarayı' ifadeleri kullanılmıştır. Bu binanın hizmete girmesinin ardından, son olarak resmi kararla Cumhurbaşkanlığı Külliyesi ismiyle tanımlanmıştır.

Yerleşke, iktidara muhalif kesim tarafından Ak-Saray olarak anılmış/ halen anılmaktadır. Batuman (2019, s.254) bu tanımlamanın; "Ak" ön ismi ile AK Parti'ye bir gönderme, "Saray" ifadesi ile (eski) Cumhurbaşkanlığ1 "Köşkü" kıyası yoluyla "israfa" dikkat çekmek için kullandığını ifade etmiştir. Muhalefetin bu olumsuz yönde ele aldığı tanımlamaya rağmen, Ahmet Davutoğlu TRT'de katıldığı yayında yerleşke için "Ak-Saray" ifadesini kullanarak (Diken, 2014), bu isimlendirmeyi gayr1-resmi biçimde yeniden kurgulamıştır. Çınar (2020, s. 142), "saray" ifadesinin "bir savurganlığın, görgüsüzlügün, ulus-devlet çağına, demokrasi anlayışına ayak uyduramamanın, tek adam rejiminin bir tezahürü olarak algılanabilir" olmasına karşın iktidar partisi tarafından "...otantik özün bir gereği olarak altın çağın yaşandığg Osmanlı döneminin" göstereni olarak kullanımına devam edildiğini ifade etmektedir. Yerleşkenin saray olarak anılması biryandan tarihsel referansı ve itibar ile ilişkilendirilmiş, diğer yandan gösteriş ve israfla şifrelendirilerek farklı anlam yükleri ile kullanılmıştır.

"Ak" kelimesinin, her ne kadar "temiz, dürüst" anlamları ile güven çağrışımı amaçlı kullandığı düşünülse de, doğrudan Ak Parti ile özdeşleşmiş bu ifadenin siyasi bir mesaj içermesi nedeniyle "...en azından resmiyette 2017 y1lında gerçekleştirilen referanduma kadar Cumhurbaşkanı'nın tarafsızlık zorunluluğuna ters düşmektedir" (Çınar, 2020, s. 145). Belki de bu sebeple, 29 Ekim 2014 yılında Erdoğan tarafından açılışı yapılan yerleşkenin resmi adı "Cumhurbaşkanlığ 1 Sarayı" olarak ilan edilmiştir.

Ancak "saray" tabiri ile pekiştirilerek; gerek güçler dengesi üzerinden yönetime yönlendirilen eleştiriler, gerekse yerleşkenin açıklan(a)mayan maliyeti ile tamamen dikkatleri çeken gösterişli mimari, dekorasyon ve günlük harcamalarına yönelik "israf ve gösteriş̧" iddiaları devam etmiştir. Bu eleştiri ve iddiaların olumsuz etkileri sebebiyle olsa gerek, yerleşkenin adı 7 Tem- 
muz 2015'te "Cumhurbaşkanlığ1 Külliyesi" olarak tekrar değiştirilmiştir. Batuman (2019, s. 254) "külliye" tabirinin kullanılması ile hem “Osmanlı geçmişine" yapılan göndermenin sürdürüldügüünu hem de "camiyi öne çıkararak tartışmaların odağını gösterişten sekülerizme" çekme amacı olduğunu ifade etmiştir.

Cumhurbaşkanlığı Yerleşkesinin "Külliye" olarak tanımlanması, kelimenin mimari terim anlamının "cami ile birlikte kurulmuş... yapıların bütünü" (TDK, 2019) olması sebebiyle oldukça tartışmalı bir ifade haline gelmiştir. Bu isimlendirme tartışması, laik bir devletin resmi Cumhurbaşkanlığı makamını içeren yapılar bütünü içinde caminin fiziksel varlığına ilişkin gündemi gölgede bırakmıştır. Çünkü fiziksel durumda, cami bir ibadet mekânı olarak sosyal bir işlevi yerine getiren bir yapı iken külliye tanımıyla cami, Cumhurbaşkanlığını oluşturan yapılar bütününün anlamsal merkezine oturtulmuştur. Hatta bu yerleşke, konuşma dilinde ve basında Cumhurbaşkanlığı yerine k1saca sadece "Külliye" olarak da anılmaktadır.

Yerleşke, Yapılaşma, Yapı Grubu, Kompleks, Kampüs: Arapça kökenli bu sözcük (Külliye) için TDK sözlügünnde geçen ikinci anlamın "Belli bir idari, ekonomik, kültürel ve sosyal amaca yönelik çeşitli kuruluşların toplu bir biçimde bulunduğu yer" olarak belirtilmiş olması, bu tanımı meşrulaştırmak için öne sürülen açıklamalardan biridir. Ancak kelimenin Türkçe karşılığ olan ve terim anlamı ile kapsadığı dini içerikten yalıtmak için önerilen "yerleşke" kelimesi tercih edilmemiştir. Bunun yerine külliye kelimesinin farklı örneklerle kullanımı sürdürülerek kabul görmesi için ısrar devam etmiştir.

Örneğin; 31.10.2018 tarihinde, TBMM Başkanı Vekili Mustafa Şentop, bütçe görüşmeleri sırasında TBMM yerleşkesi için birçok defa "Külliye" ifadesini kullanmıştır. Bu ifade ile başlayan tartışma sonrası farklı vekillerin itiraz ve eleştirileri üzerine Şentop, "Külliye” tabiri kullanımını Atatürk üzerinden meşrulaştırmak için, Clemens Holzmeister'la beraber TBMM inşaatında görev almış Mimar Ziya Payzın’ın TBMM yapılarını konu alan “Kemal Paşa Külliyesi ve Yedi İlkesi” kitabının başlığını öne sürmüştür (TBMM, 2018).

Külliye tanımının kullanımı Cumhurbaşkanlığı Yerleşkesi ile sınırlı kalmamıştır. TBMM için bu girişim kabul görmese de, üniversite gibi yerleşkeler için gerek kelimenin "yapı grubu" anlamını meşrulaştırmak gerekse dini faaliyeti bedesten, medrese, kervansaray, aşevi, şifa evi gibi yapılarla ticaret, eğitim gibi işlevlerle sosyal hayatla bütünleştiren bu yapı grubunun anlamsal 
içeriğini pekiştirmek için kullanımı yaygınlaştırılmıştır ${ }^{11}$. Örneğin yakın zamanda açılışı Cumhurbaşkanı tarafından yapılan İbn Haldun Üniversitesi Külliyesi için Anadolu Ajansı muhabirine açıklamada bulunan Rektörün beyanında; Üniversite yerleşkesinin ismine ve cismine (mimarisine) ek olarak eğitim içeriğinin de "geleneksel" ve "İslam medeniyetine" uygun biçimde yapılandırıldığını (AA, 2020) ifade etmesi dikkat çekicidir.

Milletin Evi ve Milletin Diğer Mekânlarn: Daha önce de ifade edildiği üzere Cumhurbaşkanlığı Yerleşkesi; Erdoğan'ın Başbakanlığı döneminde Başbakanlık Hizmet Binası olarak inşasına başlanmış, Erdoğan'ın Cumhurbaşkanı seçilmesi ile işlevi Cumhurbaşkanlığı olarak değiştirilmiştir. Gerek bu sebeple, yapıların temsil ettiği kuruma değil makamda bulunan kişiye yapıldığı eleştirileri gerekse yapıların gösteriş ve maliyetine yönelik tartışmalar üzerine, bu mekân "Milletin Evi" olarak ilan edilmiştir.

Ev ifadesi (White House örneğinde de belirtildiği gibi) aile kavramı ve sadeliğe vurgu yapmaktadır. Hatta bu ev, "Milletin Evi"dir. Bu tanımlamayla; yapının aidiyeti, sahipliği halka yüklenerek kişiye özel yapı, israf ve gösteriş eleştirileri bertaraf edilir. Ev kavramının ve millete aidiyetin yarattığ zihinsel imgeler basinda görsel medyayla da desteklenir.

Yerleşke içinde bulunan sosyo-kültürel mekânlar olan kütüphane, cami ve kongre merkezi gerek isimlendirmeleri (Millet Kütüphanesi, Beştepe Millet Camii ve Beştepe Millet Kongre ve Kültür Merkezi) gerekse kamuya açık olarak nitelendirilmesi yapıların "millete" ait olduğu vurgusu yapmaktadır. Yerleşkede bulunan cami ve kütüphane halka açıktır, ancak millete ait olan bu yere "millet davet ve misafir edilmekte", başka bir ifade ile milletin kullanımına müsaade edilmektedir. Bununla birlikte 2015 yılında "ziyarete açlan" yerleşkenin idari binalar, ana bina ve bahçeye girişleri özel izinle ve rehber eşliğinde sadece cuma günleri, sınırlı sayıda kişi ile gerçekleştirilebilmektedir.

Akademik yıl açılışı ve adli yıl açılış törenlerinin yerleşkede bulunan kongre merkezinde yapılması, bu kurumların bağımsızlığı ilkesinin mekânsal temsilleri üzerinden tartışılmıştır. 2019-2010 adli yıl aç1ış töreninin Cumhurbaşkanlığı Yerleşkesinde yapılması nedeniyle bazı barolar tepki göstererek törene katılmama kararı almıştır. Bu eleştirilere cevaben Erdoğan "... Bu mekân şahsıma ait değil. Bu mekân, her zaman söylediğim gibi milletin

\footnotetext{
11 Örneğin; Ankara Yıldırım Beyazıt Üniversitesi Esenboğa Merkez Külliyesi, İbn Haldun Üniversitesi Külliyesi, Külliye Karabük. Külliye üniversiteler konusu için ayrıca bkz. Ghulyan, 2019, s. 138-141; Ghulyan, 2017, s. 299-302.
} 
evi. Ve devletin tüm kurumları bu mekânı rahatlıkla kullanma hakkına sahiptir..." diyerek cevap vermiştir (TCCB, 2019). Ancak gerek bu törenlerin usul ve kuralları gerekse organizasyonun formatı sebebiyle Cumhurbaşkanlığı makamının ev sahibi konumunda, kurumların ise misafir olarak bulunduğu bir düzen işaret edilmektedir.

Aidiyeti millete devredilen mekânlar Cumhurbaşkanlığı Yerleşkesi ile s1nırlı kalmamıştır. Tüm yurt genelinde, 19. yy. Osmanlı batılılaşma dönemi "Millet Bahçeleri" referanslı isimlendirmeleriyle Millet Bahçeleri ve Millet K1raathaneleri yapılmaktadır. "Millet" kelimesi bu mekânların etiketi haline gelmiştir.

\section{Tartışma ve Sonuç}

Kentin anlatısı, pek çok sosyolojik ve mekânsal imgelemle birlikte deşifre edilmesi gereken, anlamlarla yüklü, çok katmanlı bir metindir. Mimarlık, mekânsal ilişkiler ve işlevlerle ilettiği mesajların yanı sıra sembolik anlamlarla yüklü imgelerle bilişsel bir dil kurmaktadır. Bu metinsel dil; mekân deneyimlenmediği, görülmediği zaman dahi mekânın zihinde kurgulanmasını sağlayan anlamları aktarır ve bellekte yer eder.

Toplumsal olarak üretilen mekân, bir metin olarak yine kolektif hafızanın bir parçası ve ürünüdür. Mekânın, metinsel imgelemi toplumsal belleği kurguladığı gibi, toplumsal hafıza da mekâna ait izleri anlatı ve söz üzerinden kurar. Dolayısıyla kenti bir metin gibi okuyabilmek için kentsel peyzaj öğelerini kendi ilişki sistemi içerisinde değerlendirmek gerekir. Çünkü kent hem toplumsal hem mekânsal ilişkiler sistemi içerisinde var olur. Sonuç olarak kentin hangi kavramsal düzlemde, hangi temsil alanında okunduğu toplumsal boyutun ve mekânsal boyutun göz ardı edilmemiş olması açısından önemlidir.

Kenti yalnızca mekânsal çözümleme dilleriyle incelemek, düz anlamların ortaya çıkmasına olanak verirken toplumsal ilişkiler sistemi içinde yer alan kültürel ve tarihsel anlamlar içeren işaretleri deşifre etmemize yardımcı olamaz. Kentsel anlatıda kültürel ve tarihsel anlamlar içeren işaretler yeni bir içerik düzleminde değerlendirildiğinde ve iletilen yeni bir kavramla birleştiklerinde ikincil bir anlam belirtirler. Yan anlamların ortaya çıtığı bu ideolojik süreç sonunda yeni mekân göstergeleri dolayısıyla yeni peyzaj okumalan gerçekleşir. $\mathrm{Bu}$ nedenle çalışmada göstergebilimin yöntemlerinden faydalanılmıştır. Çünkü göstergebilimin uygulama alanı farklı anlam katmanlarındaki ilişkiler sistemini anlamamızı ve yan anlamları okumamızı kolaylaştırmıştır. 
Kentsel anlatıda ideolojik süreci temsil eden ögelerden birisi de yer isimleridir. Bu anlatının temsil alanı içinde yapacağımız bir çalışmada yan anlamların okunması bu bağlamda önemlidir. Yalnızca kültürel ve tarihsel anlamlar içeren işaretleri değil toplumsal belleği oluşturan göstergeleri de deşifre etmemize yardımcı olmuştur. Modern öncesi kentlerde mekân, işlev ve mahiyete göre kullanıcıları yani toplum tarafından belirlenirken; 18.yy sonrasında mekân isimleri iktidarın temsili, geçmişin yeniden üretimi ve geleceğin bugünde arşivlenmesinin bir aracı olmuştur. Bir siyasi aktivite haline gelen yer adlandırması, iktidarın temsilini mekân üzerinden günlük hayatla buluşturur. Yer adlandırmalarının en önemli örnekleri ise temsil mekânları ile karşımıza çıkmaktadır.

Gerek merkezi gerek yerel yönetimlerde yaşanan belirgin değişimlerde kentsel yer adlandırmalarında nitelik ve nicelik açısından kırılmaların olduğu görülmektedir. Yeni rejimin kurulması ile tüm kentlerde kavramlar, olaylar ve kişi isimleri ile adlandırılan mekânlar üzerinden yeni bir toplumsal hafıza kurma hedeflenmiştir. 1950'lerde değişen siyasi kimlik, kentsel mekânda yeniden isimlendirmeler ile yeni bir temsil biçimine gönderme yapmıştır. Ankara'da yerel yönetimin değişim ile 1994-95 yıllarında yer isimlerinde nicelik olarak büyük bir değişimin yaşandığı, son on yılda ise isimlerin anlam yükü açısından nitelik değişimi olduğu görülmektedir. Ayrıca mekânı, farklı bir mekânın niteliği ile yeniden tanımlamak için tür adının kullanımı örneği Cumhurbaşkanlığı Yerleşkesi üzerinden saray, külliye ve ev kavramlarının anlamsal içeriği ile halen tartışmaların odağında olan bir konu olarak gündemdedir. Bu yerleşkenin fiziki yapısı, işlevi, kurulduğu alan vb. odaklı siyasi eleştirileri gölgede bırakacak boyuta gelen isim konusu, yer adlandırmalarının toplumun inşası, bellek, mekân ve iktidar ilişkileri açısından önemini ortaya koymaktadır.

Kültürel bir olgu olarak isimlendirme, birey ve toplumun dünyasını yansıtan dilsel bir davranıştır. Buna göre yer isimleri de toplumun dünya görüşü, deneyimleri ve inançlarını yansıttığı ölçüde benimsenirler. İktidarın bir egemenlik ve kontrol aracı olarak günlük yaşama yerleştirdiği yer isimleri, toplum tarafından (ideolojik) bir filtreden geçirilir ve ancak toplum kendi ile ilişkilendirdiği ölçüde sahiplenir. Toplumla sosyal ve kültürel olarak bağ kuramayan yer isimleri belirgin bir dirençle karşılaşır. Özellikle temsil mekânlarında isim değişikliklerinin toplumsal bellekte tam anlamıyla yer edinemediği anlaşılmaktadır. Bununla birlikte yer isimlerinde kullanılan, değiştirilen kavram ve tanımlar kamuoyu tarafından (bazen amaçtan bağımsız olarak) 
iktidarın bu isme yüklediği düşünülen anlam yükü bakımından değerlendirilmektedir.

Kentin anlatısı farklı anlam katmanlarının arkasında gizlenen sosyal ve kültürel kodların birlikteliğinden oluşur. Mekânların fiziksel muhtevası kentlinin deneyimleri ve kentsel bilinciyle birlikte değerlendirildiği zaman bu anlam katmanlarını deşifre etmemize ve anlamlandırmamıza yardımcı olur. Ancak o zaman kentin tarihini, kültürünü ve kimliğini anlatan hikâyeyi yazmaya başlayabiliriz. 


\title{
Extended Abstract
}

\section{(Re)Structuring the Space in Language: Place Names, Collective Memory and Ideology}

\author{
Seda Arslan \\ ORCID: 0000-0003-0973-8071
}

\author{
Zeynep Uludağ \\ ORCID: 0000-0001-9242-7957
}

The city can be conceptualized as a text; as a system of signs and symbols conveying messages and meanings like culture. However, this text cannot be conceptualized without reference to spatial and social processes at the same time. The spatial environment, which has many meanings behind it and conveys messages to us; it turns into a social and cultural narrative with our experiences, spatial behaviour, cognitive perception and memory. Thus, the communicative language of space is included not only in its physical content, but also its place in memory, its image in perception, and its concept in thought. Spatial perception is generated not only through physical and operational features such as form, scale, style, position, and function, but also through ideological discourses. In addition to spatial definitions such as monumentality, representation, identity, and publicity shaped by the visual perception, the narrative of the urban space also establishes, changes, and strengthens its meaning and context with textual/ linguistic messages. The narrative defines the space like a written text or a speech, while it also provides its cognitive construction.

The communicative function of the space brings together the spatial disciplines and the phenomenon of language on a common ground that is the study field of semiology. Language as a tool of communication is a system of signs which have written/spoken symbols with "concrete" expressions and perceived symbols with "abstract/conceptual" expressions. Symbolic connotations of conceptual expressions emerge as functional meanings as long as they convey the social use value of an object. In other words, in the definition values of some concepts, social/cultural meanings precede as its function. 
The words we use in describing spaces also have the conceptual expressing both their function and symbolic meaning. These definitions can be words that are used to indicate the type of the space, as well as words to be used to name that space. Words like street and boulevard, which we use to define the type of the space, are considered as the functional representation, while the words like house and palace that are used to define the typology of some buildings are considered to have a social representational meaning.

Place names are public by nature; as such they belong to the collective memory. Besides their physical characteristics they convey social and cultural meanings and messages. Place names that connect language and space; are means/forms of production of official history, recording memory and a political representation both as a part of daily life and bureaucratic field. Place naming as a political practice "embedded in language" connect the ideology with the daily activities of human life to construct a new social reality. The renaming of the places is relatively a simple political action/process/practice according to long term ideological and structural changes since it has an immediate effect on human life and perception with its power of declaration. Therefore, it is seen that the subjects of the studies that deal with urban place naming are mostly concentrate on regime and power changes.

It is a frequently encountered and controversial political act that governments represent their ideologies through renaming places in cities. In that way they introduce a new memory into the daily life of the citizens. In these study contemporary examples of this political practice of place naming and name changing in Turkey are explored over two cases: the specific term and the generic term.

In the capital city of Ankara, after the 90's, an intense urban place renaming procedure took place under the authority of the Ankara Metropolitan Municipality. This (re)naming practice is significant both in terms of quantitative results especially soon after the political party change of Municipality administration and in terms of characteristics of the names that give references to represent Turkish-Islamic civilizations and culture. These place naming establishes a connection with the Turkish-Islamic civilization and history in the urban space, creating a new meaning and memory. The local government offers a reminder and a declaration with the names of places in daily life that reaches everyone and every day by combining Turkish-Islamic history and related concepts which are assumed as its source of political legitimacy. Moreover, there are outstanding examples of place renaming process in the Capital city such as Kızılay (Red Crescent) Square, Gar (Station) Square and Tandoğan Square. 
(re)Naming of representational spaces are significant examples since these places as the meeting area, the living space of social life and public sphere, form spatial traces, urban identity, culture and collective memory.

Current place (re)naming activities are not limited to the capital city Ankara and they do not remain in the street scale. Especially large-scale projects and representational spaces have been the subject of discussions and criticisms of place re-naming process in Turkey. Although it is not limited to these examples; (re)naming of Opera Square in Ankara, 1071 Malazgirt Boulevard, third bridge built over İstanbul Bosporus, the Atatürk Square in İzmir (known as Konak Square in the collective memory), Millet Garden in Rize-Find1kl, Istanbul Atatürk Culture Centre (AKM) and new İstanbul Airport have been the subjects of discussions on place names. In other words, renaming the places over commemorative "specific term" are considered in terms of the semantic axis that is thought to be attributed by the political power to ideology over place name.

In place names, there are also examples where the terminology indicating the type of the place (generic term) with different meaning attributions. The most known example for this situation can be shown as the "White House", the official residence and office of the Presidency of the United States of America (USA). Building group gone through renaming process twice, in the $19^{\text {th }}$ century and in the $20^{\text {th }}$ century, from President's Palace to Executive Mansion and then to White House. The palace and mansion are residences that express an autocratic regime and splendour, while the house emphasizes the concept of family and simplicity.

In general, most of the countries, define presidential office and residential structures as palace while villa, mansion, castle other few typological preferences that represent massive scale, grandeur and monumentality. Moreover, it is seen that the word "house" is used in many examples as well as the word palace. Although the word palace that is used for different public buildings with judiciary, security, cultural function often adds affirmative meaning while it is used for the presidential offices, it evokes authoritarian regimes thus implies undesirable meanings by the administration.

Another similar example to the situation of redefining the space through a different spatial typology is the Presidential Complex situated on AOÇ land in Ankara. This facility is built as a multi-purpose complex with religious, social and cultural functions including the Presidential Residence and offices, administrative buildings of the affiliated units, a mosque, a congress centre and a library. Since its construction it has been named officially and unofficially with 
different symbolic definitions; "Ak-Saray" (White Palace), "Presidential Palace", "Presidential Külliye" (a mosque centred multipurpose complex), "House of the Nation". Formal and informal naming for this complex caused critics and aroused discussions in terms of its symbolic coding referring to imperial history and religious function.

The narrative of the city is a multi-layered text attributed with meanings that needs to be deciphered together with sociological and spatial imaginations. Even the space is not experienced or seen, this textual language of space conveys the meanings that enable to (re)construct it in memory. Place names are one of the elements representing the ideological process in the urban narrative. In this context, it is important to read connotations within different representational fields of urban narrative that lead to decode, not only the signs that contain cultural and historical meanings, but also the signs that make up the social memory. Discussions on (re)naming of places that may overshadow the physical structure, function, political critics and/or events took place, reveals its importance in terms of construction of society, collective memory, space and power relations. As a result, it is understood that this (re)naming process encounters the resistance of collective memory especially for representational space, unless the place names reflect the world view and beliefs or associated with daily life and spatial experiences of the society.

\section{Kaynakça/References}

AA. (2020, Ekim 19). İḦ̈'yü 'kampüs üniversite' kimliğine kavuşturan külliye açldt. 23 Ekim 2020 tarihinde Anadolu Ajans: https://www.aa.com.tr/tr/egitim/ihuyu-kampus-universite-kimligine-kavusturan-kulliye-acildi/2011400 adresinden erişildi.

ABB. (t.y.). Değişen cadde ve sokak isimleri. 01 Kasım 2020 tarihinde Ankara Büyükşehir Belediyesi, Numarataj Şube Müdürlüğü: https://www.ankara.bel.tr/genel-sekreter/genel-sekreter-yardimcisi/fen-isleri-dairesi-baskanligi/numarataj-sube-mudurlugu/degisen-cadde-ve-sokak-simleri/ adresinden erişildi.

Akarsu, B. (1984). Wilhelm Von Humboldt'da dil-kültür bağlantısı. İstanbul: Remzi Kitabevi. Akduman, İ. (2020, Haziran 26). Millet Bahçesi'nin adını Atatürk Parkı olarak değiştiren CHP'li başkana soruşturma. 15 Kasım 2020 tarihinde Sözcü: https://www.sozcu.com.tr/2020/gundem/millet-bahcesinin-adini-ataturk-parki-olarak-degistiren-chpli-baskana-sorusturma-5896467/ adresinden erişildi.

Alderman, D. H. (2009). Street names as memorial arenas: the reputational politics of commemorating Martin Luther King Jr. in a Georgia County. L. D. Berg, ve J. Vuolteenaho (Der.), Critical Toponymies: The Contested Politics of Place Naming içinde (ss. 179-197). Surrey; Burlington, VT: Ashgate. 
Arkitera. (2013, Mayıs 30). Yavuz Sultan Selim Köprüsü' tartışma yarattı. 03 Kasım 2020 tarihinde Arkitera: https://www.arkitera.com/haber/yavuz-sultan-selim-koprusutartisma-yaratti/ adresinden erişildi.

Assmann, J. (2015). Kültürel bellek: eski yüksek kültürlerde yazı, hatırlama ve politik kimlik. (A. Tekin, Çev., 2. bs.). İstanbul: Ayrıntı. (Orijinal eserin yayın tarihi 1997).

Atay, T. (2015, Kasım 10). Erdoğan neden 'Atatürk' demekten kaçınıyor? 03 Kasım 2020 tarihinde Hürriyet: https://www.cumhuriyet.com.tr/yazarlar/tayfun-atay/erdogan-neden-ataturk-demekten-kaciniyor-412005 adresinden erişildi.

Azaryahu, M. (1997). German reunification and the politics of street names: the case of East Berlin. Political Geography, 16(6), 479-493.

Batuman, B. (2015). Gezi'nin devamı olarak Atatürk Orman Çiftliği mücadelesi ya da rejim değişikliğinin (ve buna direnişin) mecrası olarak "Cumhurbaşkanlığı Sarayı". Dosya, 1(34), 53-62.

Batuman, B. (2019). Milletin mimarisi-yeni İslama ulus inşasınn kent ve mekân siyaseti. İstanbul: Metis.

Batur, A. (1998). 1925-1950 döneminde Türkiye mimarlığı. 75 yılda değişen kent ve mimarlık içinde (ss. 209-234). İstanbul: Tarih Vakfı Yayınları.

Bayer, Y. (2017, Haziran 20). AKM'de Atatürk adı 'uçuruluyor' mu?. 03 Kasım 2020 tarihinde Hürriyet: https:/www.hurriyet.com.tr/yazarlar/yalcin-bayer/akmde-ataturkadi-ucuruluyor-mu-40495410 adresinden erişildi.

Bigler, B. P. (2020). White House. Encyclopædia Britannica. 22 Ekim 2020 tarihinde Brittanica: https://www.britannica.com/topic/White-House-Washington-DC adresinden erişildi.

Cengizkan, A. (2004). Ankara'nın ilk planı: 1924-25 Lörcher Planı. Ankara: Ankara Enstitüsü Vakfı, Arkadaş Yayınları.

Cengizkan, A. (2017). Kurgu, tasarım ve kullanım: Cumhuriyet dönemi kamusal mekânları için bir çalışma programı. G. A. Sargın (Dü.), Başkent üzerine mekân-politik tezler: Ankara'nın kamusal yüzleri içinde (4. bs., s. 215-243). İstanbul: İletişim Yayınları.

Çağlar, N., Uludağ, Z., ve Aksu, A. (2006). Hürriyet Meydanı: bir kentsel mekânın yenilik ve dönüşüm öyküsü. Gazi Üniversitesi Mühendislik MimarlkkFakültesi Dergisi, 21(1), 177-182.

Çaralan, İ. (2018, 10 31). İstanbul Havalimanı açıldı ama başlattı̆̆ı tartışmalar sürecek. 02 Kasim 2010 tarihinde Evrensel: https://www.evrensel.net/yazi/82570/istanbul-havalimani-acildi-ama-baslattigi-tartismalar-surecek adresinden erişildi.

Çınar, R. Ü. (2020). Ecdadın icadı: AKP iktidarında bellek mücadelesi. İstanbul: İletişim.

Çoban M. (2013). Toplumsal hafıza ve siyasal dönüşümler bağlamında mekân isimlerinin önemi: Türkiye örneği, VII. Ulusal Sosyoloji Kongresi, Bildiri Kitabı III, s 667-675.

David, J. (2013). Street names-between ideology and cultural heritage. Acta Onomastica, 54(1), 53-61.

Diken. (2014, 1kasım1 09). 9 Soruda dünyanın dilindeki 'Ak Saray'. 03 Kasım 2020 tarihinde Diken: http://www.diken.com.tr/9-soruda-ak-saray-2/ adresinden erişildi. 
Diken. (2015, Ekim 15). AKP'ye 'barış' fazla geldi: Gar Meydanı'nın adı 'Demokrasi Meydanı' olarak değiştirildi. 03 Kasım 2020 tarihinde Diken: http://www.diken.com.tr/akpyebaris-fazla-geldi-gar-meydaninin-adi-demokrasi-meydani-olarak-degistirildi/ adresinden erişildi.

Eco, U. (2019). Mimarlık göstergebilimi. (F. Erkman Akerson, Çev.). İstanbul: Daimon. (Orijinal eserin yayın tarihi 1968).

Gazeteduvar. (2017, Temmuz 15). 09 Kasım 2020 tarihinde Gazeteduvar: https://www.gazeteduvar.com.tr/gundem/2017/07/15/15-temmuz-sonrasi-nerelerin-adi-degisti. adresinden erişildi.

Gazeteport. (2015, Kasım 10). 03 Kasım 2020 tarihinde Gazeteport: http:/gazeteport.com/2015/neden-ataturk-demiyor-2030/ adresinden erişildi.

Ghulyan, H. (2017). Mekânın üretimi kuramı ve Türkiye'de kentsel mekânın üretimi: Ankara örneği. Ankara: Yayınlanmamış Doktora Tezi, Ankara Üniversitesi Sosyal Bilimler Enstitüsü.

Ghulyan, H. (2019). The spatialization of Islamist, populist, and neo-Ottoman discourses in the Turkish capital under AKP rule. New Perspectives on Turkey, 2019(61), 125-153.

Giddens, A. (1995). The constitution of society, outline of the theory of structuration. Cambridge: Polity Press.

Günal, V. (2012). Batman'da cadde adlandırmaları: toplumsal bellek oluşturma ve şehirsel mekâna hâkim olma çabaları. Marmara Coğrafya Dergisi, Sayı: 25, s.171-197.

Gür, B. F., \& Altan, T. E. (2015). İktidarın gösteri(ş) mekânı: Cumhurbaşkanlığı Kompleksi. Dosya, 34, 1-6.

Gürsel, K. (2019, Kasım 12). Erdoğan Atatürkçü mü oldu? 03 Kasım 2020 tarihinde Medyascope: https://medyascope.tv/2019/11/12/yorum-kadri-gursel-18-erdogan-ataturkcu-mu-oldu/ adresinden erişildi.

HaberSol. (2017, Temmuz 15). 30 Ekim 2020 tarihinde Haber.Sol: https:/haber.sol.org.tr/toplum/iste-15-temmuzdan-sonra-ismi-degistirilen-yerler-202934 adresinden erişildi.

Halbwachs, M. (2018). Kolektifbellek. (Z. Karagöz, Çev.) İstanbul: Pimhan. (Orijinal eserin yayın tarihi 1950).

Harvey, D. (1975). Social justice and the city. London: Edward Arnold Ltd.

Hürriyet. (2016, Ağustos 09). 02 Kasım 2020 tarihinde Hürriyet: https://www.hurriyet.com.tr/izmir-buyuksehir-belediyesinde-gundem-15-temmu-40186113 adresinden erişildi.

Hürriyet. (2018, Temmuz 15). 30 Ekim 2020 tarihinde Hürriyet: https://www.hurriyet.com.tr/gundem/sehitlerin-isimleri-buralarda-yasayacak-40896706 adresinden erişildi.

Kara, B. (2012). Kentler açısından mekânın toplumsallığı ve yer isimlerinin siyasal yapıya göre değişimi: Niğde örneği. Journal of World of Turks, 4(1), s. 149-163.

Lefebvre, H. (1993). The production of space. Oxford: Blackwell. 
Milliyet. (2015, Nisan 15). Mitinglerin meydanı 'Tandoğan'sı kaldı. 02 Kasım 2020 tarihinde Milliyet: https://www.milliyet.com.tr/gundem/mitinglerin-meydani-tandogan-sizkaldi-2044152 adresinden erişildi.

Mills, C. W. (1959). Social imagination. New York.

Mimarlar Odası-Ankara. (2016, Temmuz). Mekânsal izler kolaycr yöntemlerle oluşturulamaz... hafiza reddeder!. [Kurul Açılaması] 10 Ekim 2020 tarihinde Mimarlar OdasıAnkara Şubesi: http://www.mimarlarodasiankara.org/index.php?Did=7957 adresinden erişildi.

Nash, C. (1999). Irish placenames: post-colonial locations. Transactions of the Institute of British Geographers, 24(4), 457-480.

NTV. (2015, Ekim 15). Ankara Gar Meydanı'nın ismi değişti. 02 Kasım 2020 tarihinde NTV: https://www.ntv.com.tr/turkiye/ankara-gar-meydaninin-ismi-degisti,ZZIUQ8pHxEG7Bb6rIA-u-Q adresinden erişildi.

Özberk, N. (2018). Mekânsal semiyotik ve politik semantik açısından kentsel metnin dönüşümü: Nevşehir'de kamusal mekân isimlendirmeleri örneği. İdealkent, 9(24), 662700.

Özkan, M., ve Yoloğlu, A. C. (2005). Bir bellek projesi olarak sokak isimlendirmesi: Ankara örneği. Planlama, 2005 (4), 54-60.

Sami, F. (2016, Şubat 07). Markalaşma her alanda önemlidir, komik ama bir o kadar da gerçek bir örnek..Emlak fiyatları ve konut isimleri! @fuatsami: https://twitter.com/fuatsami/status/696301454722785280?s=20 adresinden erişildi.

Sayer, A. (1991). Behind the locality debate: deconstructing geography's dualisms. Environment and Planning (A), 23, 283-308.

Saussure, F. D. (2011). Course in general linguistics. (W. Baskin, Çev.) New York; Chichester, West Sussex: Columbia University Press.

Stoughton, C. Kennedy children visit the Oval Office. President Kennedy, Caroline Kennedy, John F. Kennedy ,Jr. White House, Oval Office.

T24. (2013, Mayıs 29). 3. Köprü için Yavuz Sultan Selim adı neden tartışma yarattı? 03 Kasım 2020 tarihinde T24: https://24.com.tr/haber/sabiha-gokcen-havaalanina-in-yavuzsultan-selim-koprusunden-gec,230901 adresinden erişildi.

T24. (2018, Nisan 01). 03 Kasim 2010 tarihinde T24: https://t24.com.tr/haber/catlayin-patlayin-akmyi-yiktik-diyen-erdogana-tepki-yol-gorundu-gidecek-ataturkun-adini-silemeyecek,594893 adresinden erişildi.

Tamur, E. (2010). Ankara'da mahal isimlerine yansiyan tarih-I. Kebikeç, 29, 57-71.

Tan, P. K. (2018). Challenges to nationalism in language planning: street names in Malaysia. Researching Agency in Language Policy and Planning (s. 61-83) içinde Routledge.

TBMM. (2018, Ekim 31). Komisyon Tutanakları. 06 Haziran 2020 tarihinde TBMM: https://www.tbmm.gov.tr/develop/owa/komisyon_tutanaklari.goruntule?pTutanakId=2195 adresinden erişildi. 
TCCB. (2017, Kasım 10). Konuşmalar. 09 Kasım 2020 tarihinde Türkiye Cumhuriyeti Cumhurbaşkanlığı: $\quad$ https://www.tccb.gov.tr/konusmalar/353/87289/ataturkuanma-toreninde-yaptiklari-konusma adresinden erişildi.

TCCB. (2019, Eylül 02). Konuşmalar. 09 Kasım 2020 tarihinde Türkiye Cumhuriyeti Cumhurbaşkanlığı: https://www.tccb.gov.tr/konusmalar/353/109470/adli-yil-acilis-toreninde-yaptiklari-konusma adresinden erişildi.

TDK. (2019). Külliye. 20 Haziran 2020 tarihinde Türk Dil Kurumu Sözlükleri: https://sozluk.gov.tr/ adresinden erişildi.

Turan, S., ve Yalçıner Ercoşkun, Ö. (2017). Meydanlardaki isim değişikliklerinin kent belleğine etkisi: Ankara örneği. Mimarlık Bilimleri ve Uygulamaları Dergisi, 2(1), 55-68.

Uluşahin, A. (2017, Kasım 06). Atatürk Kültür Merkezi'nin 70 yıllık tarihi. 09 Kasım 2020 tarihinde Bianet: https://m.bianet.org/bianet/kultur/191286-ataturk-kultur-merkezinin-70-yillik-tarihi adresinden erişildi.

White House. (t.y.). The grounds: The White House Building. 22 Ekim 2020 tarihinde White House: https://www.whitehouse.gov/about-the-white-house/the-white-house/ adresinden erişildi.

Yeni Şafak. (2015, Ekim 15). 02 Kasım 2020 tarihinde Yeni Şafak: https://www.yenisafak.com/gundem/ankara-gari-meydaninin-adi-degistirildi-2323643 adresinden erişildi.

Yetkin, M. (2017, Kasım 13). Ve Erdoğan Atatürk'ü övüyorsa. 03 Kasım 2020 tarihinde Hürriyet: https://www.hurriyet.com.tr/yazarlar/murat-yetkin/ve-erdogan-ataturkuovuyorsa-40642932 adresinden erişildi.

\section{Ekler}

Tablo 4. 2013-2020 arası dönemde Başkent Ankara' da kent mekânı isimleri (ABB, t.y.).

\begin{tabular}{llll}
\hline İsimlendirme biçimi & & Sayı & Oran \% \\
\hline \multirow{2}{*}{ İlk isimlendirme } & ilk isim (isim) & 838 & 19,69 \\
\cline { 2 - 4 } & ilk isim (numara) & 3.221 & 75,68 \\
\cline { 2 - 4 } & Toplam & $\mathbf{4 . 0 5 9}$ & $\mathbf{9 5 , 3 7}$ \\
\hline \multirow{2}{*}{$\begin{array}{l}\text { İim değişiklikleri } \\
\text { (statü değişimi dâhil) }\end{array}$} & isimden isime & 57 & 1,34 \\
\cline { 2 - 4 } & numaradan isime & 140 & 3,29 \\
\cline { 2 - 4 } & Toplam & $\mathbf{1 9 7}$ & $\mathbf{4 , 6 3}$ \\
\hline GENEL TOPLAM & & $\mathbf{4 2 5 6}$ & $\mathbf{1 0 0}$ \\
\hline
\end{tabular}


Tablo 5. Başkent Ankara'da 2013-2020 yılları arasında sokak, cadde, bulvar, meydan isimlerinin nitelikleri (ABB, t.y.).

\begin{tabular}{|c|c|c|}
\hline \multicolumn{2}{|c|}{ İsimlerin Niteliği } & \multirow[b]{2}{*}{$\begin{array}{l}\text { Örnekler } \\
\text { Akşemseddin, Alparslan, Ali Kuşçu, Barbaros Hayrettin Paşa, Çandarlı } \\
\text { Halil Paşa, Enver Paşa, Ertuğrul gazi, Evliya Çelebi, Fatih Sultan Mehmet, } \\
\text { Fevzi Çakmak; Fuzuli, Gazali, Harezmi, İstemihan, Kadızade Rumi, Ka- } \\
\text { nuni, Katip Çelebi, Kılıçarslan, Köroğlu, Kültigin, Melikşah, Mevlana, Me- } \\
\text { tehan, Mimar Sinan, Nasuhpaşa, Orhangazi, Oruç Gazi, Oruç Reis, Osman } \\
\text { Bey, Osmangazi, Piri Reis, Saltuk Buğra, Selahaddin Eyyubi, Sami Efendi, } \\
\text { Süleyman Şah, Süleyman Çelebi, Ulubatlı Hasan, Uluç Ali Paşa, Yavuz Sul- } \\
\text { tan Selim, Yıldırım Beyazıt vd. }\end{array}$} \\
\hline \multirow{7}{*}{ 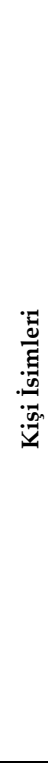 } & $\begin{array}{l}\text { Türk-İslam medeniyetleri } \\
\text { tarihinde önemli şahıslar }\end{array}$ & \\
\hline & Siyasetçiler & $\begin{array}{l}\text { Adnan Menderes, Hasan Celal Güzel, Melih Gökçek, Muhsin Yazıcıoğlu, } \\
\text { Prof. Dr. Necmettin Erbakan, Orhan Eren, Sadık Ahmet, Şükrü Saraçoğlu, } \\
\text { Prof. Dr. Turan Güven, Yücel Seçkiner }\end{array}$ \\
\hline & Şehit İsimleri & $\begin{array}{l}\text { Şehit Ömer Halisdemir, Şehit Polis Mustafa Keskin, İncek Şehit Savcı Meh- } \\
\text { met Selim Kiraz vd. }\end{array}$ \\
\hline & $\begin{array}{l}\text { Bilim, sanat, edebiyat, } \\
\text { spor alanlarında önemli } \\
\text { şahsiyetler }\end{array}$ & $\begin{array}{l}\text { Abdülrahim Karakoş, Aşık Veysel, Ali Kızltuğ, Prof. Dr. Aziz Sancar, Barış } \\
\text { Manço, Erol Yaşar Türkalp, Hasan Tahsin, Mehmet Akif Ersoy, Namık Ke- } \\
\text { mal, Necip Fazıl Kısakürek, Reşat Nuri Güntekin, Sezai Karakoç, Sinan Şa- } \\
\text { mil Sam. }\end{array}$ \\
\hline & Yabancı İsimler & Cengiz Aymatov, Andrey Karlov, Aleksander Dupçek, MalcomX \\
\hline & $\begin{array}{l}\text { Çeşitli dini } \\
\text { toplulukların temsilcisi } \\
\text { olarak anılan kişiler }\end{array}$ & $\begin{array}{l}\text { Alaaddin Fersafi, Abdullah Faruki, Aziz Mahmud Hüdayi, Galip Hasan } \\
\text { Kuşçuoğlu, Mehmet Zahit Kotku, Mustafa Kalfaoğlu, İbrahim Gürbüz, } \\
\text { Rıza Çöllüoğlu vd. }\end{array}$ \\
\hline & Diğer & $\begin{array}{l}\text { İlhan Cavcav, Hasan Basri Bozkurt, Makbule Ölçen, Fırat Yılmaz Çakıroğlu } \\
\text { vd. }\end{array}$ \\
\hline \multirow{3}{*}{ 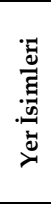 } & $\begin{array}{l}\text { Türk-İslam coğrafyası } \\
\text { yer isimleri }\end{array}$ & $\begin{array}{l}\text { Bosna, Buhara, Cezayir, Gazze, Budapeşte, Gazi Magaso, Girne, Kafkas, } \\
\text { Karabağ, Karadağ, Kerkük, Kıbrıs, Kırım, Kosova, Mekke, Podgarista, Se- } \\
\text { lanik, Semerkand, Üsküp, Türkistan, Anadolu, Avrasya, Horasan, }\end{array}$ \\
\hline & $\begin{array}{l}\text { Türkiye' den farklı yer } \\
\text { isimleri }\end{array}$ & Sakarya, Çanakkale, Kocatepe, Nevşehir, Beyşehir, Karamürsel vd. \\
\hline & Diğer yer isimleri & Rodos, Lizbon, Lozan, Tibet \\
\hline \multirow{2}{*}{ 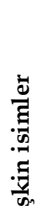 } & $\begin{array}{l}\text { Türk-İslam kültürüne } \\
\text { referans veren } \\
\text { kavramlar }\end{array}$ & $\begin{array}{l}\text { Selçuklu(lar), Ergenekon, Serhat, Hilal, Kaan, Kürşat, Ayyıldız, Diriliş, } \\
\text { Oğuz, Orhun, Otağ, Özbek, Bozkurt, Tuğra, Hünkar, Ferman, Zakir, Me- } \\
\text { dine Müdafii, Ramazan, Oruç, Hafız, Himmet, Destan, Dergah, Ehlibeyt, } \\
\text { Cennet, Cihat vd. }\end{array}$ \\
\hline & $\begin{array}{l}\text { Cumhuriyet tarihi } \\
\text { referanslı kavramlar }\end{array}$ & $\begin{array}{l}\text { Kurtuluş, İstiklal, Millet, Hürriyet, Demokrasi, Cumhuriyet, Anayurt, Bay- } \\
\text { rak, Vatan, Sancak }\end{array}$ \\
\hline
\end{tabular}

Olaylara referans

veren isimler

Amasya Beyannemsi, 19 Mayıs, Mavi Marmara, Zeytindalı (2018), 15 Temmuz Kızılay Milli İrade, 15 Temmuz Şehitler, 1071 Malazgirt, Anafartalar, Dumlupınar, Pasinler, Lozan, Mercidabık, Çaldıran, Yassıçimen, Lozan, Tanzimat, Homaç, Estergon vd.

Cevher, Çevre, Çınarlı, Çiğdem, Zambak, Mazı, Ay, Balık, Zümrüt, Yakut, Elmas, Şafak, Şelale, Tepe, Palmiye, Petek, Seher, Kaktüs, Tufan, Taşkın, Sümbül, Başak, Çelik, Bakır, Çiçek, Lale, Akarsu, Dolunay, Ladin, Limon vd.

Belediye, Okullar, Ormancılar, Sanayii, Avcılar, Camcı, Semaver, Nisa, Sa-

Diğer rılar, Tezkere, Esma, Gizem, Beste, Buğra, Ecem, Kürşat, Odak, Özışık, Dereboyu, Örenkale, Özdebirlik, Beyazçizgi, Bademli, Sağlıklı, Genç, Güvengir, Huzur, Temiz, Şefkat, Sanat, Sergi, Balerin, Bilim vd. 